\title{
New Data on the Genus Paracentrophyes (Homalorhagida, Kinorhyncha), with the Description of a New Species from the West Pacific
}

\author{
Martin V. Sørensen*,1, Fernando Pardos ${ }^{2}$, María Herranz ${ }^{2}$ and Hyun Soo Rho ${ }^{3}$ \\ ${ }^{I}$ The Natural History Museum of Denmark, University of Copenhagen, Universitetsparken 15, 2100 Copenhagen, \\ Denmark \\ ${ }^{2}$ Department of Zoology and Anthropology (Invertebrate Zoology), Faculty of Biological Sciences, Universidad \\ Complutense de Madrid, Madrid, Spain
}

${ }^{3}$ Dokdo Research Center, Korea Ocean Research and Development Institute, Uljin 767-813, Korea

\begin{abstract}
The kinorhynch genus Paracentrophyes currently consists of two species only: P. quadridentatus (Zelinka, 1928) from the Mediterranean Sea and P. praedictus Higgins, 1983 from Belize in the Caribbean. Both species have until now been recorded from their type localities only. In the present contribution a new species of Paracentrophyes, $P$. anurus sp. nov., is described from the Korea Strait. The species can be recognized by details in the mouth cone morphology, absence of perispinal setae in segment 10, and absence of a midterminal process in both sexes. Female specimens are furthermore characterized by the presence of an extraordinary long middorsal spine on segment 10 , whereas males possess a midterminal type 3 sensory spot. Besides the recording of the new species, the occurrence of $P$. cf. quadridentatus is reported from two localities in the Atlantic Ocean (Faeroe Islands and Spain). The recorded specimens are described in detail, based on combined examinations with LM and SEM, and diagnostic traits for all three species of Paracentrophyes are discussed in light of the newly acquired information. Furthermore, an emended terminology for positions of cuticular trunk structures is proposed.
\end{abstract}

Keywords: Korea, Paracentrophyes anurus sp. nov., meiofauna, taxonomy.

\section{INTRODUCTION}

During his extensive study of the Mediterranean kinorhynch fauna, Zelinka [1] described two atypical species that were assigned to the homalorhagid genus Pycnophyes. Unlike other Pycnophyes the two species, P. quadridentatus Zelinka, 1928 and $P$. flagellatus Zelinka, 1928, did not have completely differentiated episternal and midsternal plates on segment 1 , and unpaired spines were present on the two posteriormost segments. These morphological deviations from all other species in the genus made their taxonomic position doubtful. When Higgins [2], about fifty years later, explored the meiobenthos of the coral reef community at Carrie Bow Cay, Belize, he collected a new species displaying this special and unique combination of characters and he erected the genus Paracentrophyes to accommodate the new species, $P$. praedictus Higgins, 1983, and assigned it to the homalorhagid family Neocentrophyidae. Based on the sexual dimorphism observed in $P$. praedictus, he concluded that Zelinka's Pycnophyes quadridentatus and P. flagellatus represented the female and male, respectively, of the same species and assigned them to Paracentrophyes under the name Paracentrophyes quadridentatus [2]. The class homalorhagida currently consists of four genera.

*Address correspondence to this author at the Natural History Museum of Denmark, University of Copenhagen, Universitetsparken 15, 2100 Copenhagen, Denmark; Tel: +45 3532 1081;

E-mail: mvsorensen @ snm.ku.dk
The two diverse genera Pycnophyes and Kinorhynchus with 42 and 19 valid species, respectively, and the two smaller genera Neocentrophyes and Paracentrophyes with only two known species in each. Even though it accommodates two species only, Paracentrophyes is not a taxonomically unproblematic genus. Opposed to $P$. praedictus that is well described and has been examined thoroughly in subsequent studies [3], P. quadridentatus is poorly described and has not been reported since Zelinka found it in the Bay of Naples. Based on the information given in Zelinka's original descriptions, it is currently not possible to identify $P$. quadridentatus with certainty, which stresses the urgent need for a redescription of the species, based on specimens collected from the type locality.

Currently, the genus' known distribution range is restricted to the Mediterranean and the Tropical West Atlantic. In the present contribution we report the recording of Paracentrophyes from a locality in the Korea Strait and from two localities in the North Atlantic, off the North Coast of the Iberian Peninsula and in a fjord in the Faroe Islands. Due to the problematic status of $P$. quadridentatus, we can only tentatively identify the North Atlantic specimens as Paracentrophyes cf. quadridentatus, whereas the Korean recording represents a new species. The new species is described, and new information about introvert and cuticular trunk morphology are given for $P$. cf. quadridentatus. 


\section{MATERIALS AND METHODS}

The Faroese specimens of $P$. cf. quadridentatus were collected with a meiofaunal dredge from mud mixed with sand on $12^{\text {th }}$ April, 1990, at $42 \mathrm{~m}$ depth near the mouth of Kalbak Fjord on Streymoy (position: $62^{\circ} 04^{\prime} 01^{\prime \prime} \mathrm{N}$, $006^{\circ} 46^{\prime} 23^{\prime \prime} \mathrm{W}$ ). The samples were taken and kindly provided to the first author by Reinhardt M. Kristensen. The Spanish specimens of $P$. cf. quadridentatus were collected from muddy sand during the fisheries surveying campaign 'Carioca 90' performed by the oceanographic vessel Cornide de Saavedra in October,1990 for the Spanish Oceanographic Institute. Two collecting sites produced specimens, located at 179 and $168 \mathrm{~m}$ depth, respectively (position: $43^{\circ} 39^{\prime} 48^{\prime}{ }^{\prime} \mathrm{N}$, $004^{\circ} 39^{\prime} 48^{\prime \prime} \mathrm{W}$; and $43^{\circ} 35^{\prime} 00^{\prime}$ 'N , 4 $40^{\circ} 00^{\prime}$ 'W). Specimens of Paracentrophyes anurus sp. nov. were collected with a box corer from mud mixed with shell fragments on $8^{\text {th }}$ October, 2008, at $103 \mathrm{~m}$ depth in the Korea Strait (position: $33^{\circ} 40^{\prime} 33^{\prime \prime} \mathrm{N}, 126^{\circ} 04^{\prime} 33^{\prime \prime} \mathrm{E}$ ), (Fig. 1).

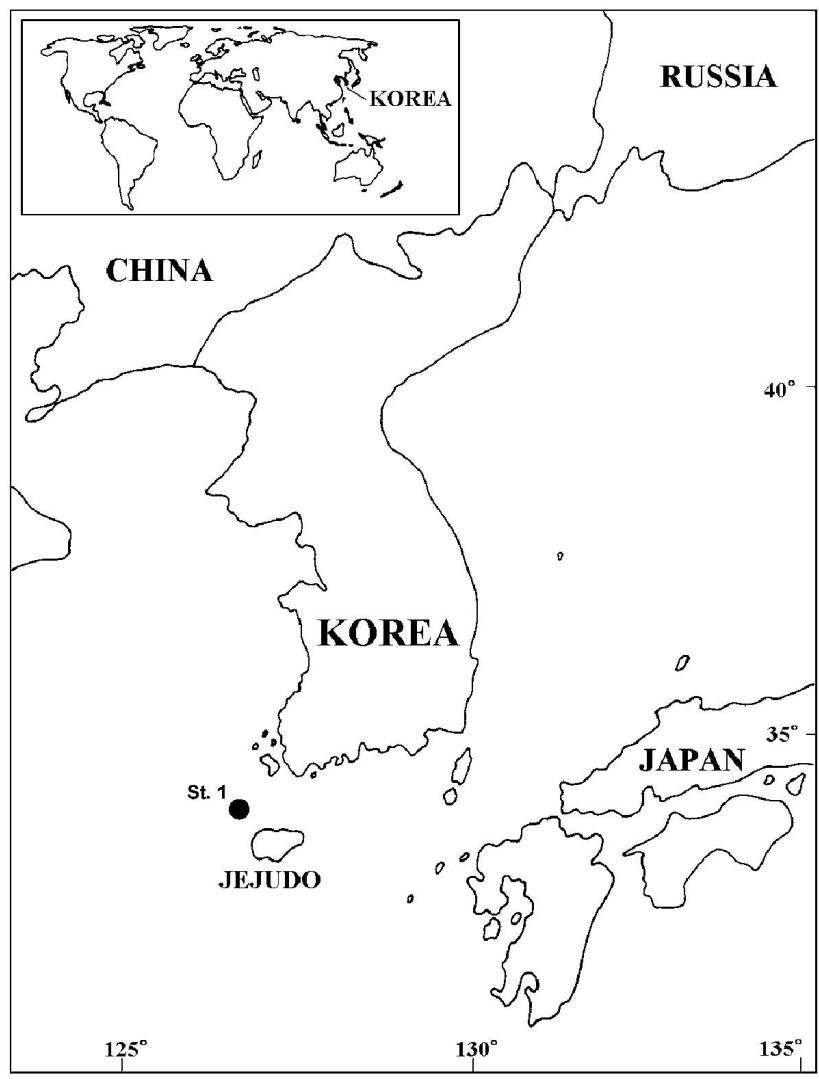

Fig. (1). Map showing type locality for Paracentrophyes anurus sp. nov. in the Korea Strait.

Kinorhynchs were extracted from the Atlantic samples using the "bubbling and blot" method (see Higgins [2], and Sørensen and Pardos [4] for updated protocol), which is efficient for extraction of meiofaunal organisms with a hydrophobic integument. The Korean samples were processed using freshwater shocking $[4,5]$ and sieving through a $63 \mu \mathrm{m}$ mesh sieve. All samples were subsequently fixed in $4 \%$ formalin buffered with sea water or borax. The kinorhynch specimens were picked out from the mixed meiobenthos under a LEICA MZ 8, a Zeiss Stemi SV6 or an Olympus SZX12 stereomicroscope.
Specimens for scanning electron microscopy (SEM) were dehydrated through a graded series of ethanol, transferred to acetone and critical point dried. The dried specimens were mounted on aluminum stubs, sputter coated and examined with a JEOL JSM 6400 or a JEOL JSM 6335F field emission scanning electron microscope. Specimens for light microscopy (LM) were transferred to distilled water, dehydrated through a graded series of glycerin and mounted in Fluoromount $\mathrm{G}^{\circledR}$. The mounted specimens were examined and photographed using Nomarski differential interference contrast with an Olympus BX60 microscope equipped with an Olympus DP20 camera, and an Olympus BX51 microscope with a DP70 camera. Measurements were made with Cell^ ${ }^{\mathrm{D}}$ software for analysis of light microscopical photos.

For comparison, allotype and paratypes of Paracentrophyes praedictus were loaned from the United States National Museum of Natural History. Type material of $P$. quadridentatus does not exist any longer.

The terminology generally follows Pardos et al. [6], Neuhaus and Higgins [7], and Sørensen and Pardos [4]. However, terminology tied to positions along the trunk cross section, as proposed by Pardos et al. [6], was designed for species of Echinoderes, and applies best to species with a trunk that appears somewhat heart-shaped in cross-section as found among species of Echinoderes and many other cyclorhagids. However, since the homalorhagid trunk appears much more triangular in cross-section, some positions needed to be redefined to apply to this shape. Definitions for positions as following can be applied to homalorhagid species and are in agreement with forthcoming studies of Sanchez et al:

\section{Middorsal}

A narrow line exactly in the middorsal position. In species of Paracentrophyes the middorsal position would usually be occupied by a middorsal spinose process or spine (see mdp and mds on Fig. 2A).

\section{Paradorsal}

Narrow lines, immediately adjacent to the middorsal position. In species of Paracentrophyes the paradorsal positions would often be occupied by perispinal setae (see pdse on Fig. 2A).

\section{Subdorsal}

Broad areas that stretch from the paradorsal positions and halfway to the paralateral positions (see definition of paralateral below). The exact position of structures (usually sensory spots only) in the subdorsal areas does not appear to be arranged along any conspicuous or well-defined longitudinal lines, hence it would not be helpful to introduce additional terms for more exact positions within the borders of the subdorsal areas. See examples of subdorsal sensory spots (sdss) on Fig. (2A).

\section{Laterodorsal}

Broad areas that stretch from the lateralmost border of the subdorsal area to the paralateral positions (see definition of paralateral below). Also in the laterodorsal area, the exact position of structures appears to vary greatly between the 
segments, hence, introducing additional positions within the borders of the areas would not be useful. See examples of laterodorsal sensory spots (ldss) on Fig. (2A).

\section{Paralateral}

This novel position refers to a narrow line dorsal to, but immediately adjacent to, the midlateral position (see definition of midlateral below). In species of Paracentrophyes the paralateral positions would often be occupied by perispinal setae (see plse on Fig. 2A) or sensory spots (see plss on Fig. 2A).

\section{Midlateral}

Narrow lines at the points where the trunk segments reach their maximum width. In species of Paracentrophyes the midlateral positions would often be occupied by midlateral spinose processes (see mlp on Fig. 2A-B).

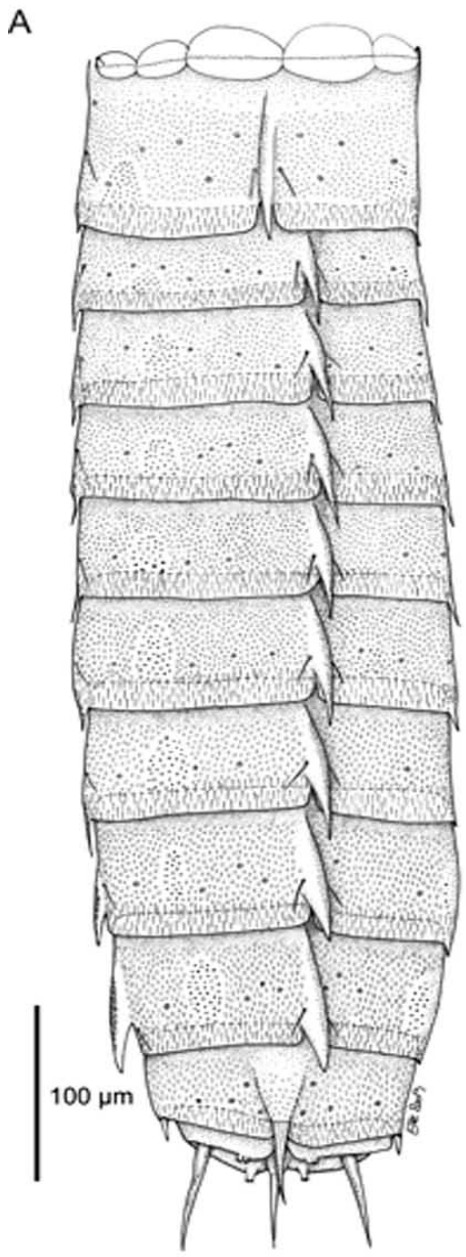

B
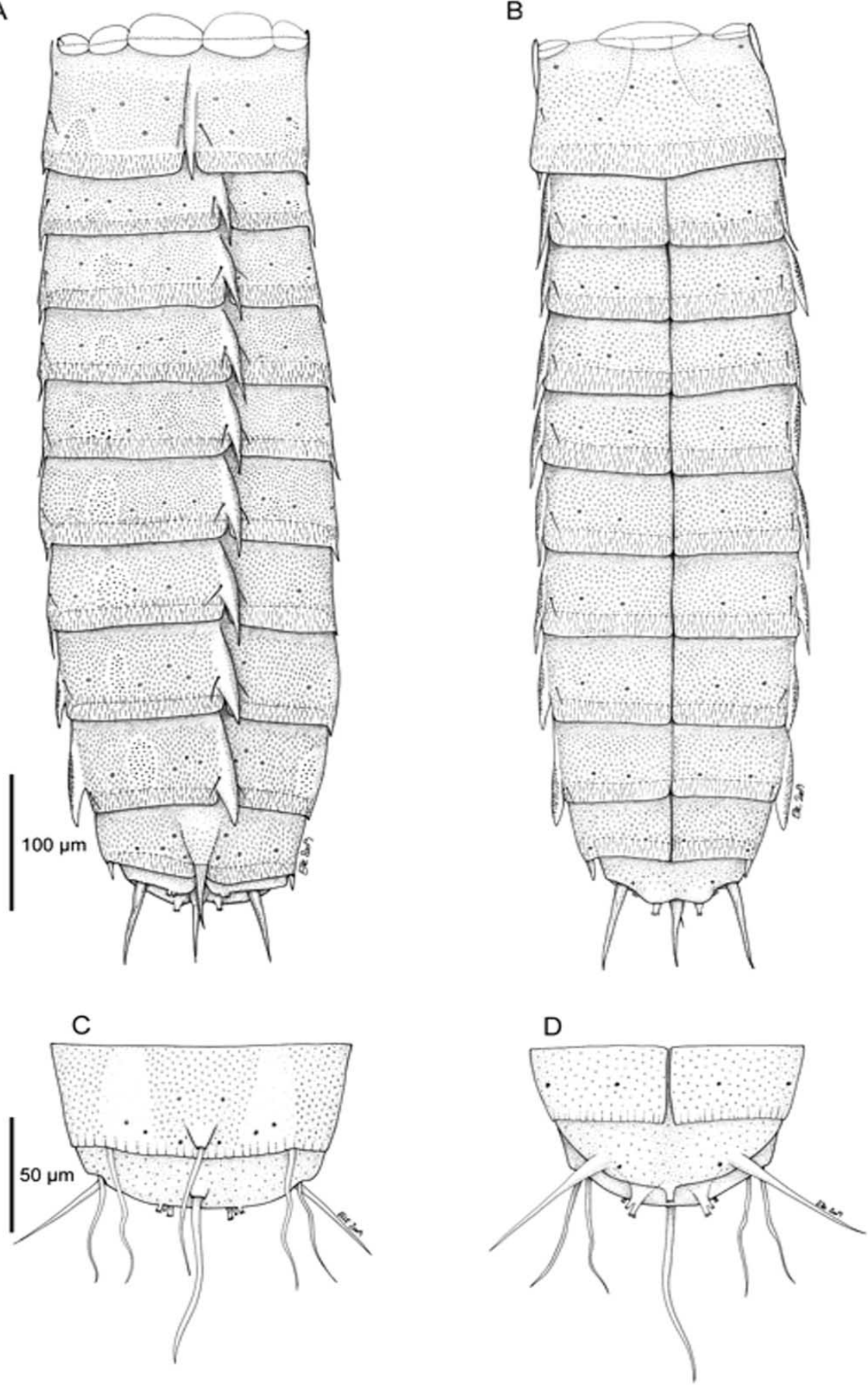

Fig. (2). Line art illustrations of Paracentrophyes anurus sp. nov. (A) Female, dorsal view. (B) Female, ventral view. (C) Segments 10 and 11 in male, dorsal view. (D) Segments 10 and 11 in male, ventral view. Abbreviations: ldss, laterodorsal sensory spot; mdp, middorsal spinose process; mds, middorsal spine; mlp, midlateral spinose process; pdse; perispinal seta; plse, paralateral seta; plss, paralateral sensory spot; sdss, subdorsal sensory spot; vlse, ventolateral seta; vlss, ventrolateral sensory spot; vmss, ventromedial sensory spot. 


\section{Sublateral and Lateral Accessory}

The terms are commonly used for positions in between midlateral and lateroventral in cyclorhagid kinorhynchs. However, due to the different trunk shape in homalorhagids, the area between the midlateral and lateroventral positions is extremely minimized, which makes location of additional positions here inapplicable.

\section{Lateroventral}

Narrow lines on the tergal plate immediately adjacent to the tergosternal junction. Structures in lateroventral positions were not recorded in any of the examined species of Paracentrophyes, but the positions are applicable for species of other homalorhagid genera.

\section{Ventrolateral}

Moderately narrow bands on the sternal plates, immediately adjacent to the tergosternal junctions. In species of Paracentrophyes the ventrolateral positions would often be occupied by perispinal setae (see vlse on Fig. 2B) or sensory spots (see vlss on Fig. 2B).

\section{Ventromedial}

Broad bands, medially on each sternal plate. In species of Paracentrophyes the ventromedial positions would often be occupied by sensory spots (see vmss on Fig. 2B).

\section{Paraventral}

Moderately narrow bands on the sternal plates, immediately adjacent to the midsternal junction. Structures

Table 1. Morphometric Data for Examined Female Specimens of Paracentrophyes: $P$. anurus sp. nov., P. cf. quadridentatus Spanish Population (P. cf. $q$. Spain), $P$. cf. quadridentatus Faroese Population (P. cf. $q$. Faeroes), and P. praedictus, Including Data Made Available by Zelinka (1928) for Type Material of $P$. quadridentatus

\begin{tabular}{|c|c|c|c|c|c|c|c|c|c|}
\hline \multirow[b]{3}{*}{ Character } & \multicolumn{2}{|c|}{ P. anurus n. sp. } & \multirow{2}{*}{$\frac{P . \text { quadridentatus }}{\text { Holotype }}$} & \multicolumn{2}{|c|}{$P$. cf. $q$. Spain } & \multicolumn{2}{|c|}{$P$. cf. $q$. Faeroes } & \multirow{2}{*}{\multicolumn{2}{|c|}{$\begin{array}{c}P . \text { praedictus } \\
\text { Allotype and } 7 \text { paratypes USNM } \\
69989 \text { and } 69989\end{array}$}} \\
\hline & $\begin{array}{l}\text { Holotype } \\
\text { KIN-341 }\end{array}$ & $\begin{array}{l}\text { Paratype } \\
\text { KIN-343 }\end{array}$ & & & & KIN-112 & KIN-113 & & \\
\hline & & & & & & & & Range & Mean \\
\hline $\mathrm{TL}$ & $630 \mu \mathrm{m}$ & $630 \mu \mathrm{m}$ & $370 \mu \mathrm{m}$ & $610 \mu \mathrm{m}$ & $539 \mu \mathrm{m}$ & $592 \mu \mathrm{m}$ & $568 \mu \mathrm{m}$ & $339-503 \mu \mathrm{m}$ & $425 \mu \mathrm{m}$ \\
\hline MSW & $162 \mu \mathrm{m}$ & $161 \mu \mathrm{m}$ & $123 \mu \mathrm{m}$ & $156 \mu \mathrm{m}$ & $136 \mu \mathrm{m}$ & $162 \mu \mathrm{m}$ & $160 \mu \mathrm{m}$ & $114-131 \mu \mathrm{m}$ & $123 \mu \mathrm{m}$ \\
\hline MSW/TL & $25,7 \%$ & $25,6 \%$ & $33,2 \%$ & $25,6 \%$ & $25,3 \%$ & $27,4 \%$ & $28,2 \%$ & $26,0-36,0 \%$ & $29,2 \%$ \\
\hline $\mathrm{S} 1$ & $96 \mu \mathrm{m}$ & $101 \mu \mathrm{m} 48$ & $65 \mu \mathrm{m}$ & $114 \mu \mathrm{m}$ & $100 \mu \mathrm{m}$ & $96 \mu \mathrm{m}$ & $100 \mu \mathrm{m}$ & $60-72 \mu \mathrm{m}$ & $66 \mu \mathrm{m}$ \\
\hline $\mathrm{S} 2$ & $54 \mu \mathrm{m}$ & $\mu \mathrm{m}$ & $27 \mu \mathrm{m}$ & $48 \mu \mathrm{m}$ & $43 \mu \mathrm{m}$ & $48 \mu \mathrm{m}$ & $43 \mu \mathrm{m}$ & $32-45 \mu \mathrm{m}$ & $37 \mu \mathrm{m}$ \\
\hline $\mathrm{S} 3$ & $56 \mu \mathrm{m}$ & $50 \mu \mathrm{m}$ & $27 \mu \mathrm{m}$ & $47 \mu \mathrm{m}$ & $45 \mu \mathrm{m}$ & $55 \mu \mathrm{m}$ & $43 \mu \mathrm{m}$ & $35-46 \mu \mathrm{m}$ & $39 \mu \mathrm{m}$ \\
\hline $\mathrm{S} 4$ & $58 \mu \mathrm{m}$ & $52 \mu \mathrm{m}$ & $31 \mu \mathrm{m}$ & $48 \mu \mathrm{m}$ & $52 \mu \mathrm{m}$ & $59 \mu \mathrm{m}$ & $48 \mu \mathrm{m}$ & $36-48 \mu \mathrm{m}$ & $40 \mu \mathrm{m}$ \\
\hline S5 & $60 \mu \mathrm{m}$ & $58 \mu \mathrm{m}$ & $31 \mu \mathrm{m}$ & $47 \mu \mathrm{m}$ & $57 \mu \mathrm{m}$ & $60 \mu \mathrm{m}$ & $48 \mu \mathrm{m}$ & $38-48 \mu \mathrm{m}$ & $42 \mu \mathrm{m}$ \\
\hline S6 & $64 \mu \mathrm{m}$ & $63 \mu \mathrm{m}$ & $38 \mu \mathrm{m}$ & $55 \mu \mathrm{m}$ & $56 \mu \mathrm{m}$ & $60 \mu \mathrm{m}$ & $64 \mu \mathrm{m}$ & $40-54 \mu \mathrm{m}$ & $44 \mu \mathrm{m}$ \\
\hline S7 & $64 \mu \mathrm{m}$ & $71 \mu \mathrm{m}$ & $38 \mu \mathrm{m}$ & $67 \mu \mathrm{m}$ & $57 \mu \mathrm{m}$ & $60 \mu \mathrm{m}$ & $64 \mu \mathrm{m}$ & $42-59 \mu \mathrm{m}$ & $47 \mu \mathrm{m}$ \\
\hline S8 & $68 \mu \mathrm{m}$ & $72 \mu \mathrm{m}$ & $42 \mu \mathrm{m}$ & $67 \mu \mathrm{m}$ & $58 \mu \mathrm{m}$ & $64 \mu \mathrm{m}$ & $64 \mu \mathrm{m}$ & $43-60 \mu \mathrm{m}$ & $48 \mu \mathrm{m}$ \\
\hline S9 & $56 \mu \mathrm{m}$ & $70 \mu \mathrm{m}$ & $46 \mu \mathrm{m}$ & $82 \mu \mathrm{m}$ & $62 \mu \mathrm{m}$ & $65 \mu \mathrm{m}$ & $64 \mu \mathrm{m}$ & $40-58 \mu \mathrm{m}$ & $47 \mu \mathrm{m}$ \\
\hline $\mathrm{S} 10$ & $46 \mu \mathrm{m}$ & $56 \mu \mathrm{m}$ & $38 \mu \mathrm{m}$ & $72 \mu \mathrm{m}$ & $54 \mu \mathrm{m}$ & $59 \mu \mathrm{m}$ & $59 \mu \mathrm{m}$ & $36-48 \mu \mathrm{m}$ & $40 \mu \mathrm{m}$ \\
\hline $\mathrm{S} 11$ & $38 \mu \mathrm{m}$ & $42 \mu \mathrm{m}$ & $23 \mu \mathrm{m}$ & $43 \mu \mathrm{m}$ & $46 \mu \mathrm{m}$ & $52 \mu \mathrm{m}$ & $47 \mu \mathrm{m}$ & $28-38 \mu \mathrm{m}$ & $32 \mu \mathrm{m}$ \\
\hline SW 1 & $134 \mu \mathrm{m}$ & $143 \mu \mathrm{m}$ & $110 \mu \mathrm{m}$ & $135 \mu \mathrm{m}$ & $129 \mu \mathrm{m}$ & $144 \mu \mathrm{m}$ & $144 \mu \mathrm{m}$ & $104-113 \mu \mathrm{m}$ & $111 \mu \mathrm{m}$ \\
\hline SW 2 & $136 \mu \mathrm{m}$ & $150 \mu \mathrm{m}$ & $123 \mu \mathrm{m}$ & $152 \mu \mathrm{m}$ & $131 \mu \mathrm{m}$ & $154 \mu \mathrm{m}$ & $151 \mu \mathrm{m}$ & $112-123 \mu \mathrm{m}$ & $118 \mu \mathrm{m}$ \\
\hline SW 3 & $148 \mu \mathrm{m}$ & $154 \mu \mathrm{m}$ & $123 \mu \mathrm{m}$ & $151 \mu \mathrm{m}$ & $135 \mu \mathrm{m}$ & $158 \mu \mathrm{m}$ & $154 \mu \mathrm{m}$ & $113-126 \mu \mathrm{m}$ & $120 \mu \mathrm{m}$ \\
\hline SW 4 & $156 \mu \mathrm{m}$ & $156 \mu \mathrm{m}$ & $123 \mu \mathrm{m}$ & $155 \mu \mathrm{m}$ & $136 \mu \mathrm{m}$ & $158 \mu \mathrm{m}$ & $158 \mu \mathrm{m}$ & $114-129 \mu \mathrm{m}$ & $121 \mu \mathrm{m}$ \\
\hline SW 5 & $162 \mu \mathrm{m}$ & $161 \mu \mathrm{m}$ & $123 \mu \mathrm{m}$ & $156 \mu \mathrm{m}$ & $134 \mu \mathrm{m}$ & $159 \mu \mathrm{m}$ & $160 \mu \mathrm{m}$ & $114-131 \mu \mathrm{m}$ & $123 \mu \mathrm{m}$ \\
\hline SW 6 & $162 \mu \mathrm{m}$ & $161 \mu \mathrm{m}$ & $123 \mu \mathrm{m}$ & $153 \mu \mathrm{m}$ & $134 \mu \mathrm{m}$ & $162 \mu \mathrm{m}$ & $160 \mu \mathrm{m}$ & $114-131 \mu \mathrm{m}$ & $123 \mu \mathrm{m}$ \\
\hline SW 7 & $162 \mu \mathrm{m}$ & $161 \mu \mathrm{m}$ & $123 \mu \mathrm{m}$ & $154 \mu \mathrm{m}$ & $133 \mu \mathrm{m}$ & $162 \mu \mathrm{m}$ & $160 \mu \mathrm{m}$ & $114-131 \mu \mathrm{m}$ & $123 \mu \mathrm{m}$ \\
\hline SW 8 & $162 \mu \mathrm{m}$ & $161 \mu \mathrm{m}$ & $123 \mu \mathrm{m}$ & $147 \mu \mathrm{m}$ & $127 \mu \mathrm{m}$ & $162 \mu \mathrm{m}$ & $160 \mu \mathrm{m}$ & $114-131 \mu \mathrm{m}$ & $123 \mu \mathrm{m}$ \\
\hline SW 9 & $150 \mu \mathrm{m}$ & $147 \mu \mathrm{m}$ & $110 \mu \mathrm{m}$ & $139 \mu \mathrm{m}$ & $123 \mu \mathrm{m}$ & $157 \mu \mathrm{m}$ & $159 \mu \mathrm{m}$ & $107-125 \mu \mathrm{m}$ & $116 \mu \mathrm{m}$ \\
\hline SW 10 & $130 \mu \mathrm{m}$ & $124 \mu \mathrm{m}$ & $100 \mu \mathrm{m}$ & $116 \mu \mathrm{m}$ & $104 \mu \mathrm{m}$ & $145 \mu \mathrm{m}$ & $144 \mu \mathrm{m}$ & $94-113 \mu \mathrm{m}$ & $103 \mu \mathrm{m}$ \\
\hline SW 11 & $98 \mu \mathrm{m}$ & $91 \mu \mathrm{m}$ & $77 \mu \mathrm{m}$ & $90 \mu \mathrm{m}$ & $83 \mu \mathrm{m}$ & $104 \mu \mathrm{m}$ & $112 \mu \mathrm{m}$ & $71-86 \mu \mathrm{m}$ & $79 \mu \mathrm{m}$ \\
\hline ML 10 & $13 \mu \mathrm{m}$ & $13 \mu \mathrm{m}$ & $23 \mu \mathrm{m}$ & Broken & $18 \mu \mathrm{m}$ & $26 \mu \mathrm{m}$ & $25 \mu \mathrm{m}$ & $11-14 \mu \mathrm{m}$ & $12 \mu \mathrm{m}$ \\
\hline MD 10 & $50 \mu \mathrm{m}$ & $56 \mu \mathrm{m}$ & $27 \mu \mathrm{m}$ & Broken & $26 \mu \mathrm{m}$ & $25 \mu \mathrm{m}$ & $30 \mu \mathrm{m}$ & $18-26 \mu \mathrm{m}$ & $23 \mu \mathrm{m}$ \\
\hline MD 11 & Broken & $40 \mu \mathrm{m}$ & $65 \mu \mathrm{m}$ & Broken & $48 \mu \mathrm{m}$ & $52 \mu \mathrm{m}$ & $43 \mu \mathrm{m}$ & $31-52 \mu \mathrm{m}$ & $41 \mu \mathrm{m}$ \\
\hline LTS & $61 \mu \mathrm{m}$ & $62 \mu \mathrm{m}$ & $96 \mu \mathrm{m}$ & Broken & $103 \mu \mathrm{m}$ & $126 \mu \mathrm{m}$ & $135 \mu \mathrm{m}$ & $95-121 \mu \mathrm{m}$ & $108 \mu \mathrm{m}$ \\
\hline
\end{tabular}

Abbreviations: LTS: lateral terminal spine; ML: midlateral spine; MD: middorsal spine; MSW: maximum sternal width; S: segment length; SW: sternal width; TL: trunk length. 
Table 2. Morphometric Data for Examined Male Specimens of Paracentrophyes: $P$. anurus sp. nov., P. cf. quadridentatus Spanish Population ( $P$. cf. $q$. Spain), $P$. cf. quadridentatus Faroese Population (P. cf. $q$. Faeroes), and $P$. praedictus, Including Data Made Available by Zelinka (1928) for Type Material of $P$. quadridentatus

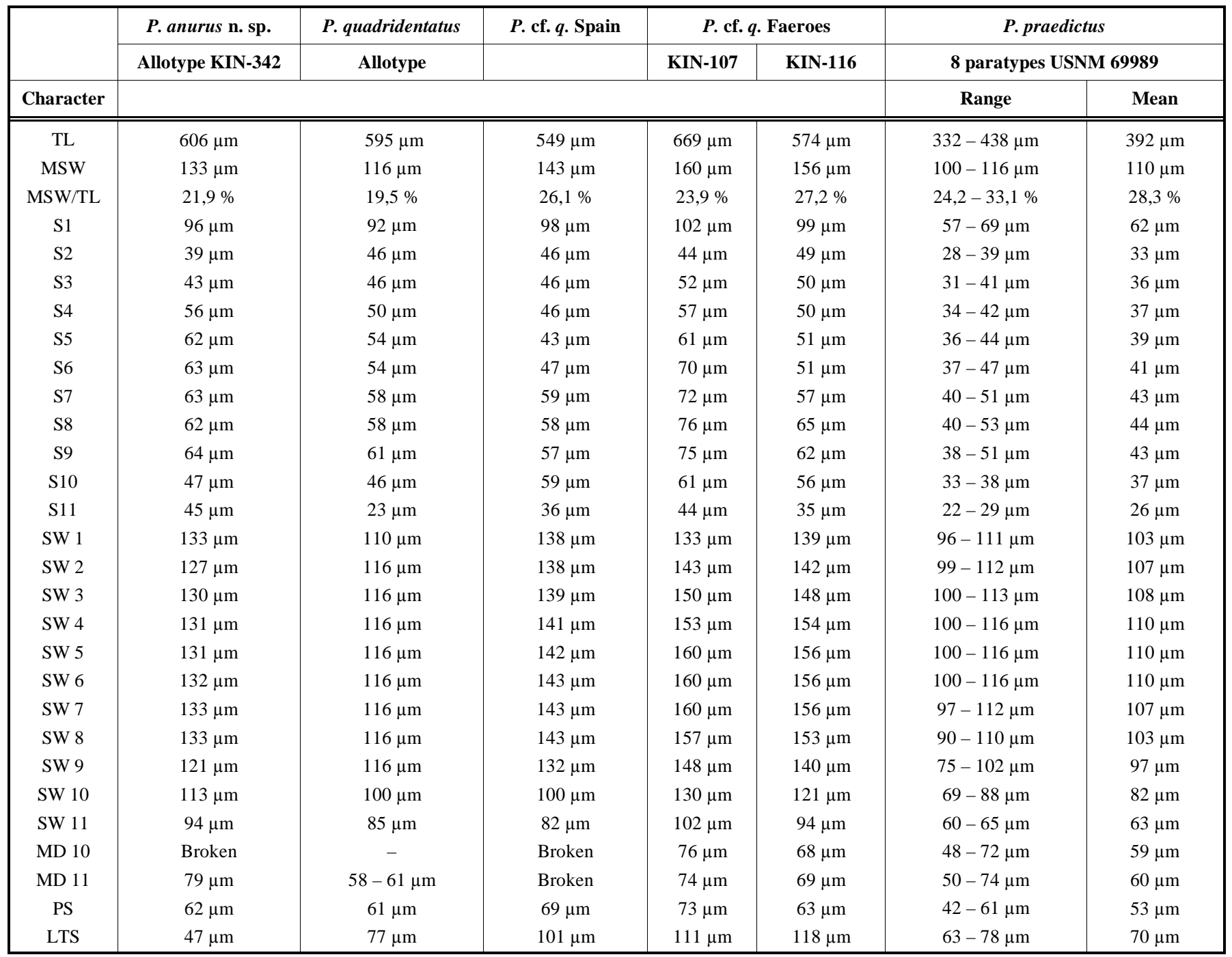

Abbreviations: LTS: lateral terminal spine; MD: middorsal spine; MSW: maximum sternal width; PS: penile spine; S: segment length; SW: sternal width; TL: trunk length. A dash (-) indicates that data is not available.

Table 3. Summary of Nature and Location of Sensory Spots, Setae, Spines and Spinous Processes Arranged by Series in Paracentrophyes anurus sp. nov. from the Korea Strait

\begin{tabular}{|c|c|c|c|c|c|c|c|c|}
\hline Position Segment & MD & PD & SD & LD & PL & ML & VL & VM \\
\hline 2 & $\mathrm{sp}$ & $\mathrm{se}$ & ss $1 \mathrm{ss} 1$ & ss1 ss 1 ss 1 ss 1 & se & $\mathrm{sp}$ & $\mathrm{se}$ & ss $1 \mathrm{ss} 1$ \\
\hline 4 & $\mathrm{sp}$ & $\mathrm{se}$ & ss1 ss1 & ss1 ss1 & se & $\mathrm{sp}$ & se & ss1 ss1 \\
\hline 5 & $\mathrm{sp}$ & se & ss 1 & ss $1 \mathrm{ss} 1$ & se & $\mathrm{sp}$ & se & ss $1 \mathrm{ss} 1$ \\
\hline 8 & $\mathrm{sp}$ & se & ss1 ss1 & ss 1 ss 1 & se & $\mathrm{sp}$ & se & ss 1 ss 1 \\
\hline 9 & $\mathrm{sp}$ & se & ss $1 \mathrm{ss} 1 \mathrm{ss} 1$ & ss 1 & se & $\mathrm{sp}$ & se & ss $1 \mathrm{ss} 1$ \\
\hline 10 & $\mathrm{ac}$ & & ss $1 \mathrm{ss} 1 \mathrm{ss} 1$ & ps (m) ss 1 & & ac (f) & ss1 & ss1 \\
\hline 11 & ac ss3 (m) & & $\mathrm{ss} 3 \mathrm{ss} 3$ & ps (m) & & lts & & ss1 ss3 \\
\hline
\end{tabular}

Abbreviations: ac, acicular spine; (f): female condition of sexually dimorphic character; lts: lateral terminal spine; (m): male condition of sexually dimorphic character; ps, penile spine; ss1/3: sensory spot type 1/3; se, perispinal seta; sp, spinous process. LD: laterodorsal; MD: middorsal; ML: midlateral; PD: paradorsal; PL: paralateral; SD: subdorsal; VL: ventrolateral; VM: ventromedial. 
in paraventral positions were not recorded in any of the examined species of Paracentrophyes, but the positions are applicable for species of other homalorhagid genera.

\section{RESULTS}

Homalorhagida Zelinka, 1896

Neocentrophyidae Higgins, 1969

Paracentrophyes Higgins, 1983

\section{Paracentrophyes anurus sp. nov.}

\section{Type Material}

Holotype, adult female, collected on Oct. $8^{\text {th }}, 2008$ in the Korea Strait (Fig. 1): $33^{\circ} 40^{\prime} 33^{\prime \prime} \mathrm{N}, 126^{\circ} 04^{\prime} 33^{\prime \prime} \mathrm{E}$, at $103 \mathrm{~m}$ depth, mounted in Fluoromount $\mathrm{G}^{\circledR}$, deposited at the Zoological Museum, Natural History Museum of Denmark, under accession number: ZMUC KIN-341. Allotype, adult male, collected with holotype, mounted in Fluoromount $\mathrm{G}^{\circledR}$, deposited at the Zoological Museum, Natural History Museum of Denmark, under accession number: ZMUC KIN342. Paratype, one adult female, collected with holotype, mounted in Fluoromount $G^{\circledR}$, deposited at the Zoological Museum, Natural History Museum of Denmark, under accession number: ZMUC KIN-343. Additional material, all collected on same date and locality as type specimens, includes six specimens (two females, three males, one juvenile) mounted for SEM. All additional material is stored in the first author's personal collection. A fresh raw sample of sediment from the locality is furthermore stored at $-80^{\circ} \mathrm{C}$ for future molecular studies.

\section{Diagnosis}

Neck with four dorsal and three ventral placids. Segments 1 and 11 consisting of one tergal and one sternal plate; segments 2 to 10 of one tergal and two sternal plates. Anterior third of sternal plate on segment 1 with indications of incomplete division into two episternal and one midsternal plate; anterior margin of segment finely denticulated. Segments 1 to 9 extend posteriorly into stout middorsal and midlateral spinous processes; spinous processes flanked by paradorsal, paralateral and ventrolateral setae. Segment 10 with middorsal and midlateral spines; midlateral spines very short and present in females only, middorsal spine long, extending over posterior margin of segment 11. Segment 11 with middorsal and lateral terminal spines; midterminal process absent in both sexes; males with midterminal type 3 sensory spot.

\section{Etymology}

The species name anurus is derived from Latin, meaning "no tail", and refers to the absence of a midterminal process, as displayed in both sexes of the new species.

\section{Description}

Adult specimens consist of a head, a neck and eleven trunk segments (Fig. 2). See Tables 1 and $\mathbf{2}$ for measurements and dimensions, and Table $\mathbf{3}$ for summary of positions of outer cuticular structures.

\section{Head and Neck}

The head consists of a retractable mouth cone and an introvert (Figs. 3, 4A-D). Internal armature of mouth cone present, but could not be examined in any of the available specimens. Outer cuticular surface of mouth cone with deep, longitudinal wrinkles (Fig. 4A). Ring 0 with nine outer oral styles that alternate in size: uneven sections, inclusive midventral section, with large, well-developed styles consisting of two joined elements; even numbered sections, exclusive middorsal section, with nonjoined, poorly developed styles (Figs. 3, 4A). All styles with basal pectinate fringe; large styles with five to seven fringe tips emerging from a narrow pedicle that attaches basally on the exterior surface of the styles. Smaller styles with ten to twelve fringe tips, wrapping halfway around the style (Fig. 4B).

The introvert has six rings of scalids and one additional ring of trichoscalids (Fig. 3). Ring 01 with ten spinoscalids consisting of a short proximal sheath-like basis and an elongate end piece (Fig. 4C-D). The exterior part on the distal margin of the basis terminates into a distinct fringe. Basis otherwise without external structures. The exterior surface of the end piece has an elongate, densely fringed area extending from its proximal part and about $1 / 5$ down towards the blunt distal tip. Distal pseudosegmentation partial, very indistinct. Ring 02 with 10 scalids consisting of a sheath-like basis and an end piece (Fig. 3). Basis with short fringe at distal margin and a narrow, elongate fringed area on the exterior surface (Fig. 4C-D). End piece smooth and flexible with pointed tip. Ring 03 with two scalids in uneven

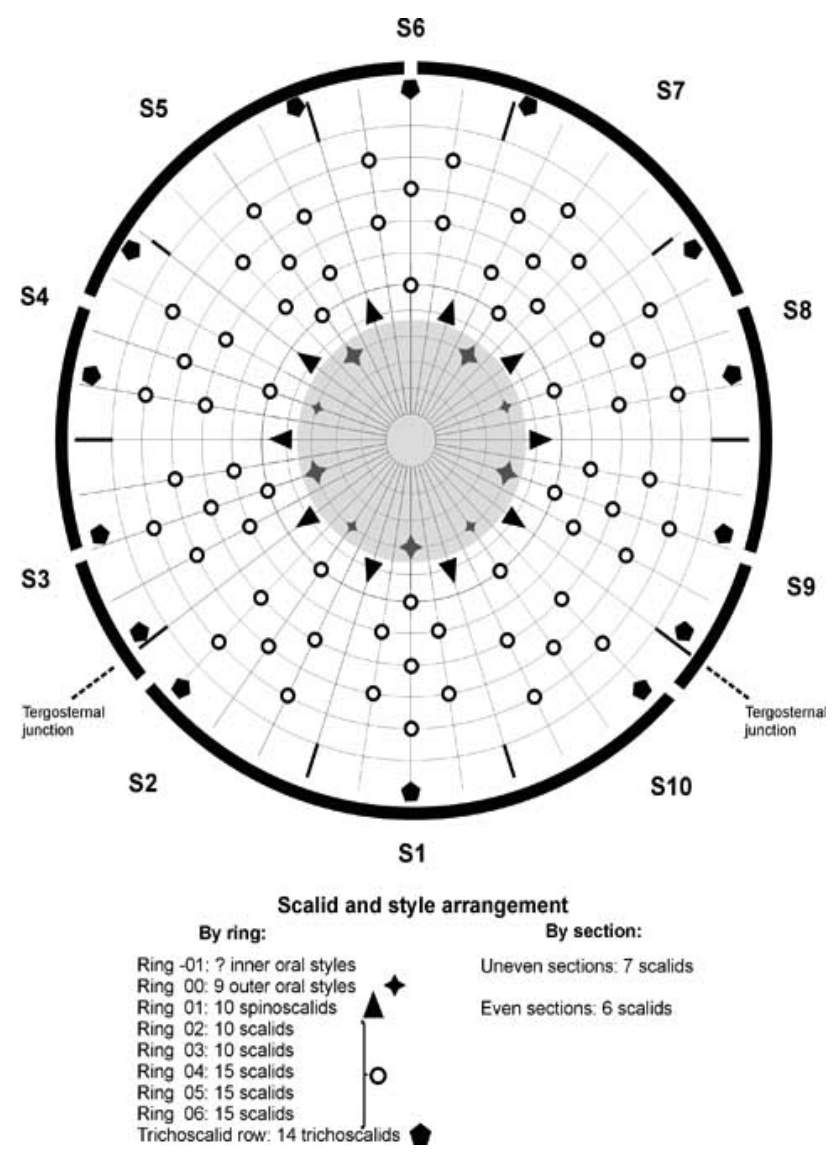

Fig. (3). Diagram of mouth cone (grey shaded area), introvert and placids in Paracentrophyes anurus sp. nov. with indication of outer oral style, scalid and placid distribution. Placids are symbolized by the bent bars around the introvert diagram. 

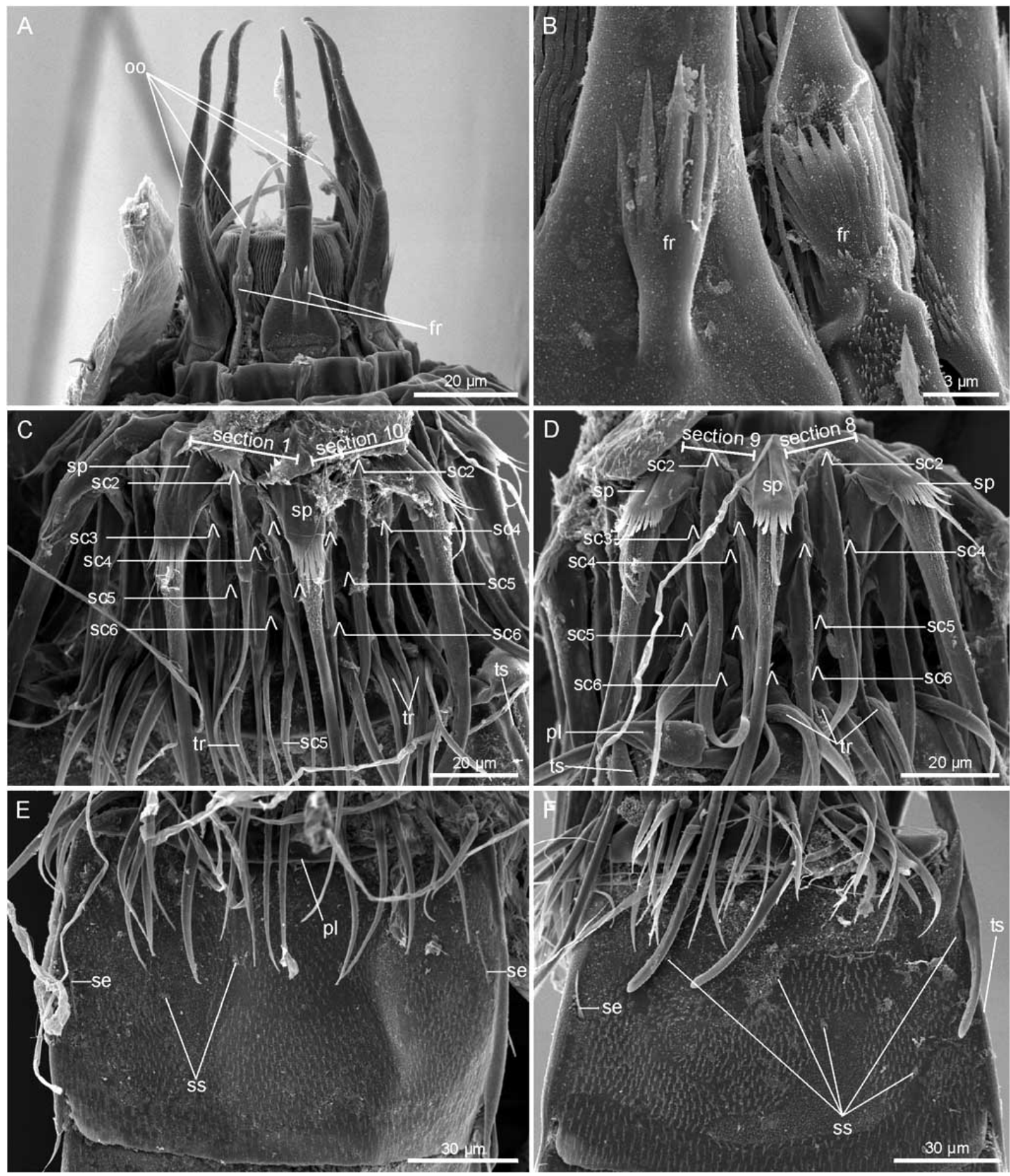

Fig. (4). Scanning electron micrographs showing details on introvert and segment 1 in Paracentrophyes anurus sp. nov. (A) Outer oral styles alternating in size. (B) Details of basal fringes on large (left) and small (right) outer oral style. (C) Introvert sections 1 (left) and 10 (right). (D) Introvert sections 9 (left) and 8 (right). (E) Sternal plate of segment 1. (F) Segment 1, right lateral side of tergal plate. Abbreviations: fr, basal fringe on outer oral style; ldss, laterodorsal sensory spot; oo, outer oral style; pdse, paradorsal seta; pl, placid; plss, paralateral sensory spot; sc, scalid; sdss, subdorsal sensory spot; sp, spinoscalid; tr, trichoscalid; ts, tergosternal junction; vlse, ventrolateral seta; vmss, ventromedial sensory spot. Digit after the labels refers to the introvert ring number. Lambda symbols $\Lambda$ mark attachment point of scalids.

numbered sections, and no scalids in even numbered ones; ring 04 with two scalids in even numbered sections, and only one in uneven numbered sections; ring 05 with two scalids in uneven numbered sections, and only one in even numbered sections; ring 06 identical with ring 04 (Figs. 3, 4C-D). The scalids in rings 03 to 06 generally show the same appearance as those in ring 02 , but become gradually shorter towards the more posterior introvert rings. Described section-wise, uneven numbered sections display a quincunx inserted between an anterior and posterior scalid, whereas even numbered sections display an anterior scalid in ring 02 followed by a gap in ring 03 and then a posterior quincunx in rings 04 to 06 (Fig. 3).

Fourteen trichoscalids are present in the most posterior part of the introvert. Their distribution is bilateral symmetrical and does not follow the section-wise displacement as found in the more anterior rings (Fig. 3). One trichoscalid is present midventrally, leaving a big gap to 

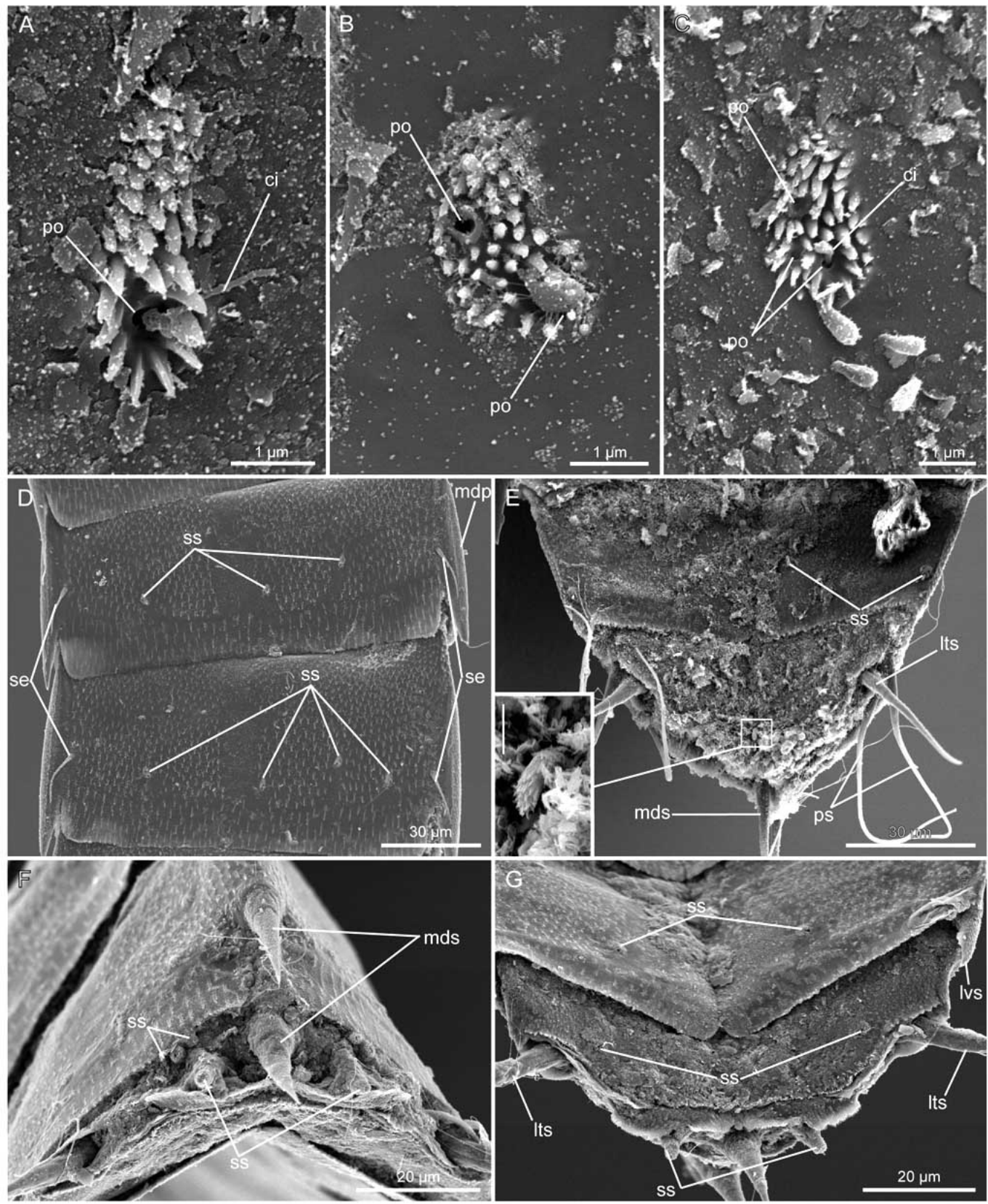

Fig. (5). Scanning electron micrographs showing cuticular trunk details in Paracentrophyes anurus sp. nov. (A) Ventromedial sensory spot with single pore on segment 3. (B) Laterodorsal sensory spot with two pores on segment 2. (C) Ventromedial sensory spot with three pores on segment 7. (D) Segments 7 to 8, left lateral side of tergal plate. (E) Segments 10 to 11 in male, ventral view. Inset shows midterminal modified sensory spot; scale: $2 \mu \mathrm{m}$. (F) Segments 10 to 11 in female, caudal view. (G) Segments 10 to 11 in female, ventral view. Abbreviations: ci, cilium; ldss, laterodorsal sensory spot; lts, lateral terminal spine; mdp, middorsal process; mds, middorsal spine; mls, midlateral spine; pdse, paradorsal seta; plse, paralateral seta; po, pore; ps, penile spine; sdss, subdorsal sensory spot; vlss, ventrolateral sensory spot; vmss, ventromedial sensory spot.

the nearest pair of trichoscalids that is located ventrolaterally, near the tergosternal junction (Fig. 4C). This pair is situated close to an additional pair in the lateroventral position (Fig. 4C). Three additional pairs of trichoscalids are distributed from the paralateral to the subdorsal positions, and one pair is situated in a somewhat paradorsal position, relatively close to the unpaired middorsal trichoscalid (Fig. 3). The trichoscalids are relatively long and densely fringed throughout their lengths. They are covered with minute scales, but do not appear shaggy (Fig. 4C-D).
The neck consists of seven soft placids (Fig. 2A-B). One very broad midventral placid stretches over most of the width of the sternal plate. A pair of lateral placids attaches near the ventrolateral position but stretches over the tergosternal junction to a somewhat paralateral position (Fig. 4D). A second pair of placids covers from the paralateral position beyond the laterodorsal and subdorsal areas, whereas a third pair stretches over the remaining parts of the subdorsal areas, to the middorsal point where they meet (Fig. 2A). 

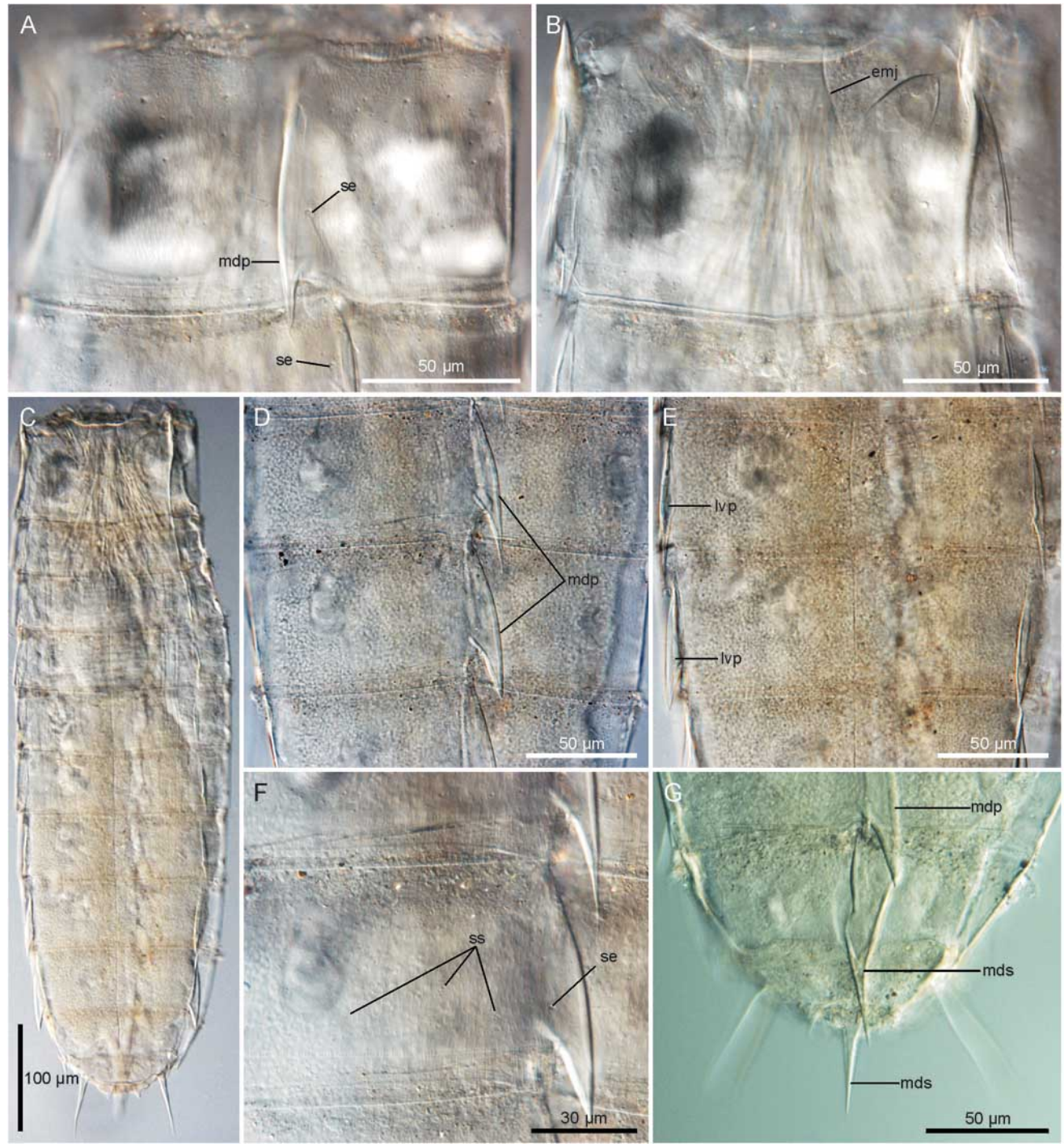

Fig. (6). Light micrographs showing cuticular and internal details in female holotype (A-F) and paratype (G) of Paracentrophyes anurus sp. nov. (A) Segment 1, dorsal view. (B) Segment 1, ventral view. (C) Entire animal, ventral view. (D) Segments 7 and 8, dorsal view. (E) Segments 7 and 8, ventral view. (F) Detail showing middorsal to subdorsal parts of segment 8. (G) Segments 9 to 11 , dorsal view. Abbreviations: emj, episternal-midsternal junction; ldss, laterodorsal sensory spot; mlp, midlateral process; mdp, middorsal process; mds, middorsal spine; pdse, paradorsal seta; sdss, subdorsal sensory spot.

\section{Trunk}

The trunk has eleven segments (Figs. 2A-B, 6C). Segment 1 consists of one tergal and one sternal plate. Incomplete lines showing a partial subdivision into paired episternal plates and an unpaired midsternal plate are indicated on the anterior part of the sternal plate (Figs. 2B, 4E, 6B). Segments 2 to 10 are composed of one tergal and two sternal plates, and segment 11 of one tergal and a single sternal plate (Figs. 2B, 5E, G, 6E). The sternal plates are flattened, whereas the tergal plate is steeply vaulted, making the trunk conspicuously triangular in cross-section (Fig. 5F).The segment width is fairly constant throughout the whole trunk, but the maximum width is reached at segment 5 , and retained until segment 8 (segments 3 to 8 in males), from which the segments gradually turn narrower (see also Tables 1-2, 5). The cuticle is of medium thickness and pachycycli are generally indistinct (Fig. 6). All segments have densely set scale-like cuticular hairs, interrupted by less hirsute areas around some sensory spots and prominent laterodorsal muscle attachment sites on segments 1 to 10 . Posterior segment margins finely serrated, but an actual pectinate fringe is not present. Secondary pectinate fringes on anterior part of segments not present.

Segment 1 with middorsal and midlateral spinose processes (Figs. 2A, 4F, 6A). Spinose processes with acicular pointed tips, and flanked by paradorsal or paralateral and ventrolateral perispinal setae. Anterior segment margin covered by overhanging placids when visualized with SEM (Fig. 4D-E). In LM the anterior segment margins appear finely denticulated (Fig. 6A). Anterolateral margins of segment extend into horn-like processes. Tergal plate with five pairs of sensory spots, and sternal plate with three pairs (two in males) (see Fig. $\mathbf{2 A - B}$ and Table $\mathbf{3}$ for exact location). All sensory spots are rounded to elongate and appear slightly elevated due to the projecting papillae. The 
sensory spots on this and the following segments may have one and up to three pores (Fig. 5A-C). Those with two or three pores resemble two or three partly merged "single pore" sensory spots. The number of pores in each particular sensory spot varies among the examined specimens.

Segment 2 with middorsal and midlateral spinose processes appearing as those on the previous segment. Spinose processes flanked by paradorsal or paralateral and ventrolateral setae. Six pairs of sensory spots evenly distributed over the tergal plate in the subdorsal and laterodorsal positions (Fig. 2A); both single and double pored sensory spots present (Fig. 5B). Sternal plates with two pairs of ventromedial sensory spots; sensory spots elongate to droplet shaped with a cilium emerging through the single pore.

Segments 3 and 4 similar with previous segment, but with only four pairs of sensory spots on the tergal plate (Fig. 2A).
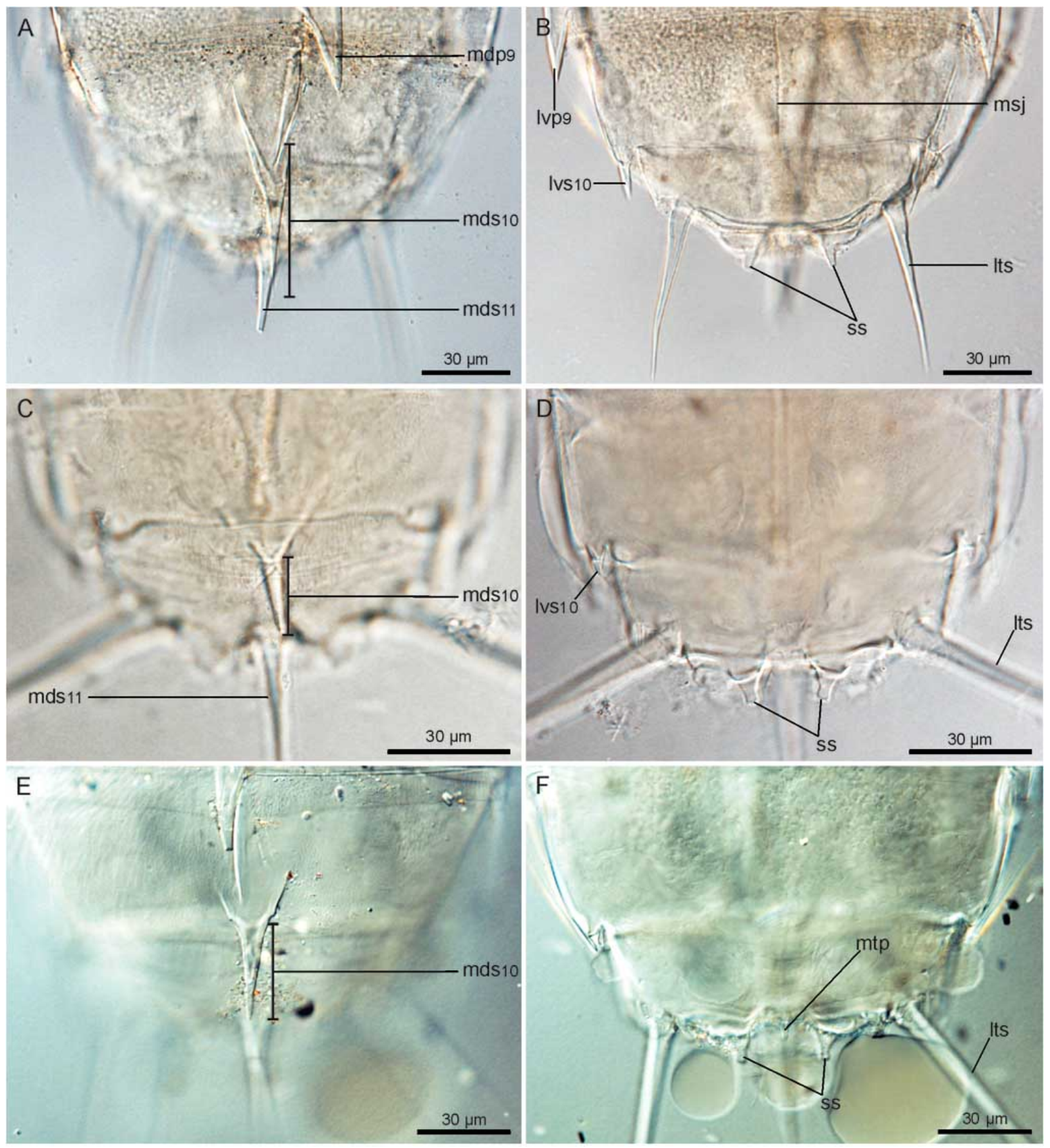

Fig. (7). Light micrographs showing terminal segments in female specimens of three species of Paracentrophyes: (A) P. anurus sp. nov. dorsal view and (B) ventral view. (C) P. praedictus dorsal view and (D) ventral view. (E) P. cf. quadridentatus (Faroese population) dorsal view and (F) ventral view. Abbreviations: lts, lateral terminal spine; mdp, middorsal process; mds, middorsal spine; mlp, midlateral process; mls, midlateral spine; msj, midsternal junction; mtp, midterminal process; vmss, ventromedial sensory spot. Digit after the labels refers to the segment number. 

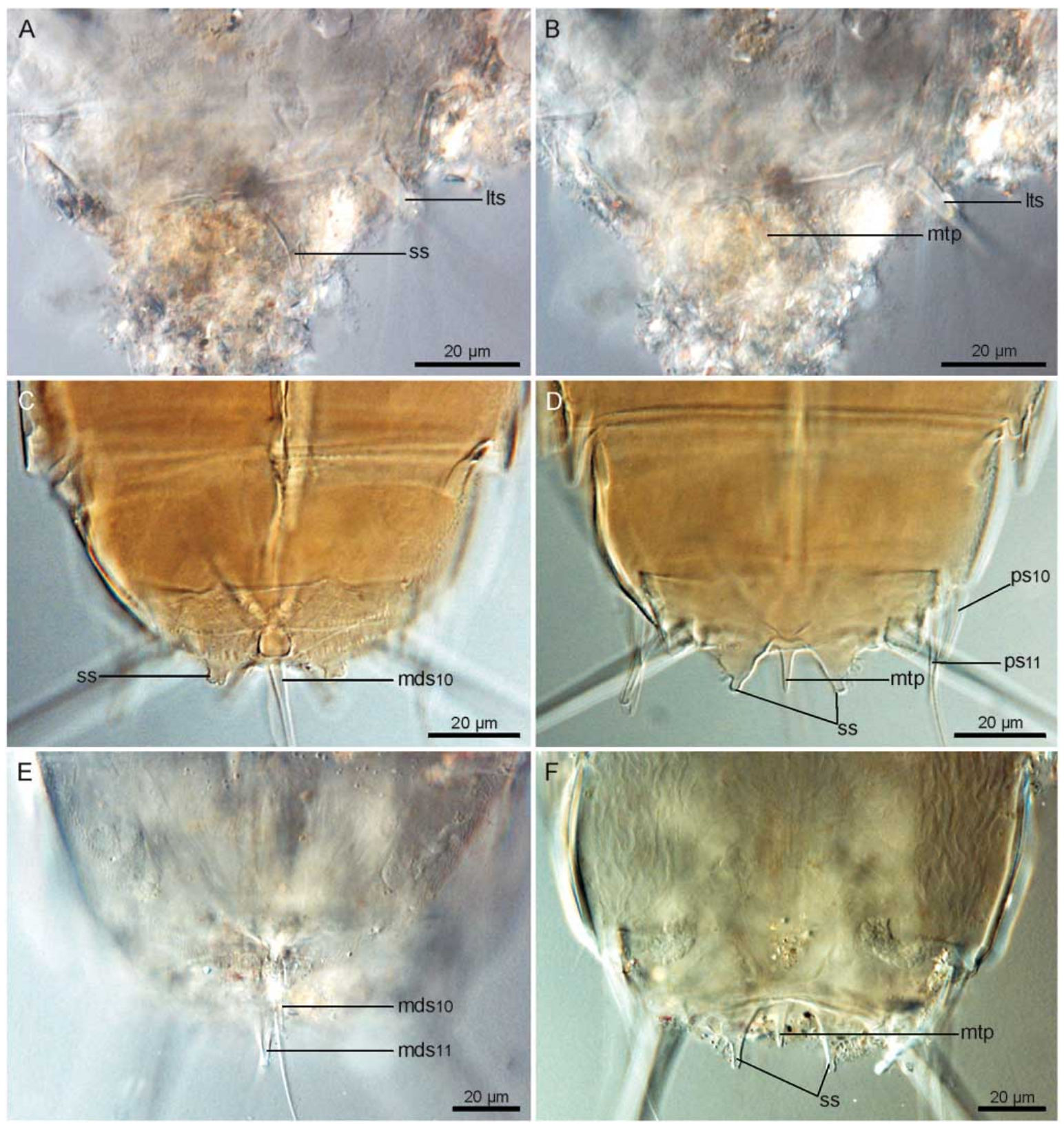

Fig. (8). Light micrographs showing terminal segments in male specimens of three species of Paracentrophyes: (A-B) P. anurus sp. nov. ventral view but yet two slightly different focus planes. (C) P. praedictus dorsal view and (D) ventral view. (E) P. cf. quadridentatus (Faroese population) dorsal view and (F) ventral view. Abbreviations: lts, lateral terminal spine; mtp, midterminal process; mds, middorsal spine; ps, penile spine; sdss, subdorsal sensory spot; vmss, ventromedial sensory spot. Digit after the labels refers to the segment number.

Segment 5 generally similar with previous two segments, but with three pairs of sensory spots only. Basis of middorsal spinose process slightly stronger than on previous segments.

Segment 6 similar with segments 3 and 4 . Basis of middorsal spinose process slightly stronger than on previous segment.

Segment 7 similar with segment 5 . Basis of middorsal spinose process slightly stronger than on previous segment.

Segments 8 and 9 generally similar with segments 3, 4 and 6. Bases of middorsal and midlateral spinose processes strong; processes stout and short, without acicular pointed tip (Fig. 6D-F).
Segment 10 without spinose processes and perispinal setae (Fig. 2A). Both sexes with a middorsal spine present, extending beyond posterior margin of segment 11 (Figs. 2A, C, 5F, 6G, 7A); middorsal spine pointed and rigid in females, flexible and soft in males. Females with one pair of short, pointed midlateral spines (Figs. 5G, 7B); males with one pair of laterodorsal, flexible penile spines (Figs. 2C, 5E). Tergal plate with three pairs of subdorsal and one pair of laterodorsal sensory spots; sternal plate with one pair of ventrolateral and one pair of ventromedial sensory spots (Figs. 2A-B, 5E, G).

Segment 11 short, barely projecting beyond previous segment. Middorsal spine and paired lateral terminal spines present (Figs. 2A-D, 5E-G, 6G, 7A-B); middorsal spine 
pointed and rigid in females, flexible and soft in male; lateral terminal spines rigid in both sexes. Males furthermore with one pair of laterodorsal, flexible penile spines (Figs. 2C-D, 5E). Midterminal process absent in both sexes, but males possess a short midterminal modified (type 3) sensory spot (Figs. 2D, 5E, 8B). Two pairs of subdorsal and one pair of ventromedial type 3 sensory spots extend from the caudal part of the segment (Figs. 2A-D, 5F-G, 7B, 8A); single sternal plate with one pair of ventromedial type 1 sensory spots (Fig. 5G).

\section{Habitat and Species Associations}

The sediment consisted of subtidal coarse mud with tiny mollusk shell particles. Paracentrophyes anurus sp. nov. co- occurred with another new the kinorhynch species Condyloderes megastigma [8], as well as other meiobenthic taxa such as nematodes (Desmoscolex sp., Tricoma sp., $T$. (Quadricoma) sp., Dracograllus sp., Richtersia sp., Sphaerolaimus sp., Ceramonema sp.), isopods, harpacticoids, halacarids, polychaetes and sipunculans.

\section{Paracentrophyes praedictus Higgins, 1983}

\section{Material Examined}

Female allotype (USNM 69988), eight male and thirteen female paratypes (USNM 69989) were examined and measured using light microscopy (see Tables $\mathbf{1}$ and $\mathbf{2}$ for measurements). The material was collected by R. P. Higgins
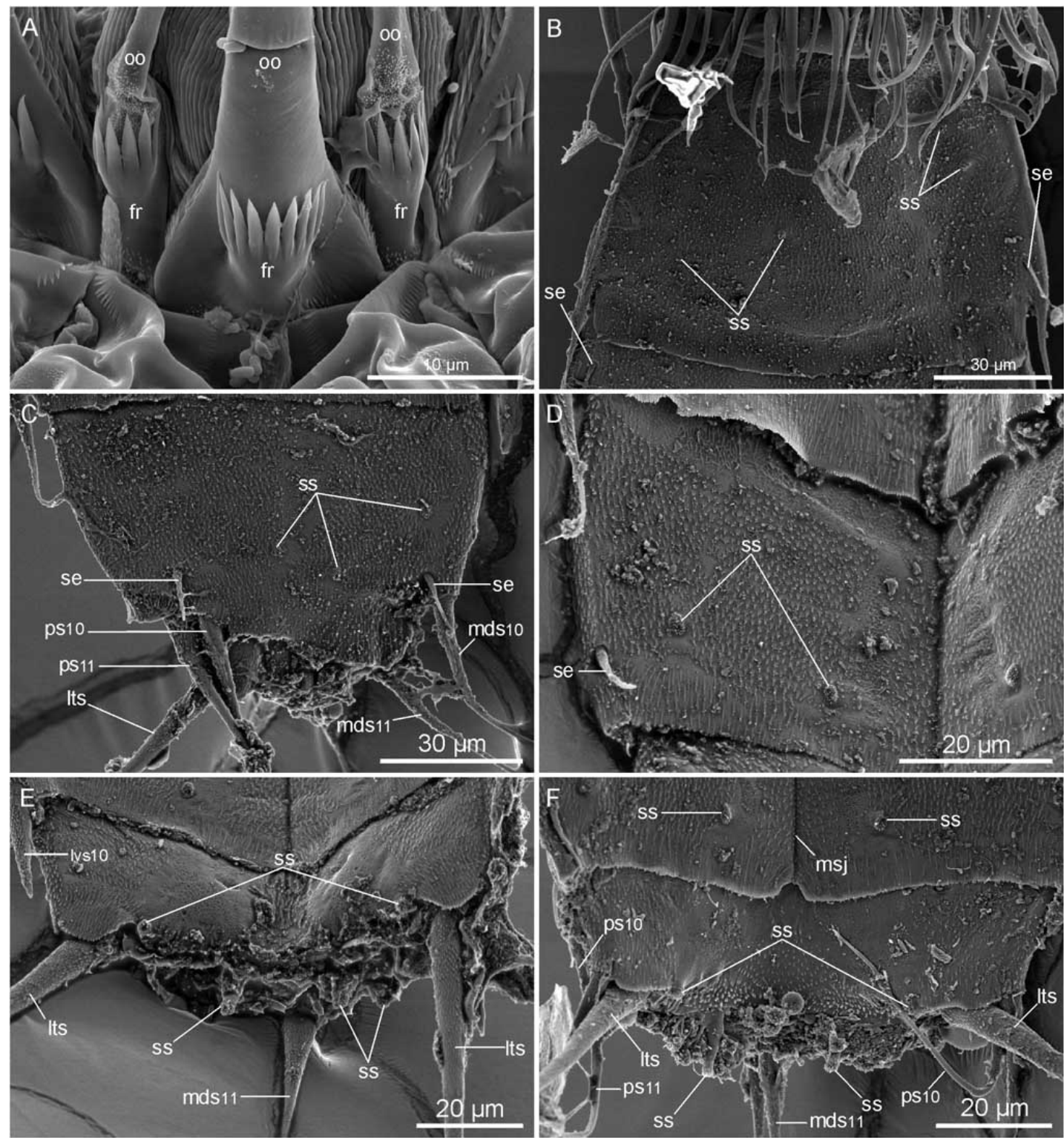

Fig. (9). Scanning electron micrographs showing cuticular head and trunk details in Paracentrophyes cf. quadridentatus from the Faroe Islands. (A) Outer oral styles alternating in size. (B) Segment 1, left lateral side of tergal plate. (C) Segments 10 and 11 in male, left lateral side of tergal plates. (D) Segment 10, right sternal plate. (E) Segments 10 and 11 in female, ventral view. (F) Segments 10 and 11 in male, ventral view. Abbreviations: fr, basal fringe on outer oral style; ldss, laterodorsal sensory spot; lts, lateral terminal spine; mds, middorsal spine; mls, midlateral spine; msj, midsternal junction; oo, outer oral style; pdse, paradorsal seta; plse, paralateral seta; ps, penile spine; sdss, subdorsal sensory spot; vlse, ventrolateral seta; vmss, ventromedial sensory spot. Digit after the labels refers to the segment number. 
at Twin Cays, Belize and is stored at the National Museum of Natural History, Smithsonian Institution.

\section{Brief Description}

All specimens were measured, and some not previously published dimensions were examined (Tables 1-2). The morphology of the re-examined specimens generally confirmed the original description given by Higgins [2] (however, sensory spot positions could not be checked due to the beginning bleaching of the specimens), but attention was drawn to some characters of particular interest. The outer oral styles alternate in size, and both large and smaller styles are equipped with a short transverse pectinate fringe on the exterior surfaces of their bases. The pectinate fringe found on the large styles has twelve fringe tips that emerge from a somewhat indistinct basis, whereas the fringes on the smaller styles tend to wrap around the style and consist of eight fringe tips. Perispinal setae are present in paradorsal, paralateral and ventrolateral positions on segments 1 to 9 . Males furthermore have one additional pair of paraventral setae on segment 1 . Segment 10 shows one pair paradorsal and ventrolateral setae in males, and paralateral and ventrolateral setae in females. Males and females furthermore possess a middorsal spine on segment 10, but the female spine is short, rigid and hardly projecting upon posterior margin of the preceding segment (Fig. 7C). Both sexes also have two pairs of subdorsal (Fig. 8C) and one pair of ventromedial (Fig. 7D, 8D) type 3 sensory spots on segment 11 . Opposed to females that have their ventromedial sensory spots projecting from short, rounded bases (Fig. 7D), males have their sensory spots elevated on the tip of a conspicuous triangular extension. The outer margin of each extension is irregular with short, thread-like outgrowths (Fig. 8D). Males also possess two pairs of penile spines, but one pair clearly emerge in a laterodorsal position from the posterior part of segment 10 (Fig. 8D), and not segment 11 as stated in the original description [2].

\section{Paracentrophyes quadridentatus (Zelinka, 1928)}

\section{Brief Description}

The type specimens collected by Zelinka in the Bay of Naples do not exist any longer, hence the only available information about the diagnostic traits for the species is contained in the original descriptions of Pycnophyes quadridentatus and P. flagellatus [1] that subsequently have been combined and reassigned to Paracentrophyes under the name $P$. quadridentatus [2]. The descriptions include some diagnostic traits and metric indices, but they do not present the amount of details required for a modern taxonomic study. Unfortunately, this limitation disables precise identification of specimens belonging to the species.

In his descriptions, Zelinka [1] provides selected measurements for a female (reported as Pycnophyes quadridentatus) and male (reported as $P$. flagellatus) specimen of Paracentrophyes quadridentatus. All reported measurements are summarized in Tables $\mathbf{1}$ and $\mathbf{2}$. The reported dimensions, as well as the provided line art illustrations, show that the trunk width is fairly constant in this species, with the sternal plates reaching their maximum width in segments 2 through 8 (9 in the male). They also show that the examined female was fairly short, only $370 \mu \mathrm{m}$ in trunk length, compared to the male with a total trunk length of $595 \mu \mathrm{m}$. However, the measures for the males should be used with some caution. Usually the sum of all individual segment lengths will exceed the total trunk length, because the segments are slightly overlapping at the intersegmental joins. However, the sum of the reported individual segment lengths is $588 \mu \mathrm{m}$ for males even though the reported total trunk length reaches $595 \mu \mathrm{m}$. Thus some of these measures must be imprecise.

Despite the lack of details in the descriptions, they still contribute with some significant information. Most importantly are the female characters showing a short middorsal

Table 4. Summary of Nature and Location of Sensory Spots (Not Available for Spanish Specimens), Setae, Spines and Spinous Processes Arranged by Series in Paracentrophyes cf. quadridentatus from the Faroe Islands and Spain

\begin{tabular}{|c|c|c|c|c|c|c|c|c|}
\hline Position Segment & MD & PD & SD & LD & PL & ML & VL & VM \\
\hline 1 & $\mathrm{sp}$ & se & ss $1 \mathrm{ss} 1$ & ss1 ss 1 & & $\mathrm{sp}$ & se ss1 & ss $1 \mathrm{ss} 1$ \\
\hline 2 & $\mathrm{sp}$ & se & ss1 ss $1 \mathrm{ss} 1$ & ss 1 & se & $\mathrm{sp}$ & se & ss 1 ss 1 \\
\hline 3 & $\mathrm{sp}$ & se & ss 1 ss 1 ss 1 & ss 1 & se & $\mathrm{sp}$ & se & ss $1 \mathrm{ss} 1$ \\
\hline 4 & $\mathrm{sp}$ & se & ss 1 ss 1 ss 1 & ss 1 & se & $\mathrm{sp}$ & se & ss 1 ss 1 \\
\hline 5 & $\mathrm{sp}$ & se & ss1 ss 1 & ss 1 & se & $\mathrm{sp}$ & se & ss $1 \mathrm{ss} 1$ \\
\hline 6 & $\mathrm{sp}$ & se & ss 1 ss 1 ss 1 & ss 1 & se & $\mathrm{sp}$ & se & ss 1 ss 1 \\
\hline 7 & $\mathrm{sp}$ & se & ss1 ss 1 & & se & $\mathrm{sp}$ & se & ss $1 \mathrm{ss} 1$ \\
\hline 8 & $\mathrm{sp}$ & se & ss 1 ss 1 ss 1 & ss 1 & se & $\mathrm{sp}$ & se & ss 1 ss 1 \\
\hline 9 & $\mathrm{sp}$ & se & ss1 ss1 & ss1 ss1 & se & $\mathrm{sp}$ & se & ss $1 \mathrm{ss} 1$ \\
\hline 10 & $\mathrm{ac}$ & se & ss 1 ss 1 ss 1 & $\mathrm{ps}(\mathrm{m})$ & se & $\mathrm{ac}(\mathrm{f})$ & se & ss $1 \mathrm{ss} 1$ \\
\hline 11 & ac mtp* & & ss $3 \mathrm{ss} 3$ & $\mathrm{ps}(\mathrm{m})$ & & lts & ss 3 & ss 1 \\
\hline
\end{tabular}

Abbreviations: ac, acicular spine; (f): female condition of sexually dimorphic character; lts: lateral terminal spine; (m): male condition of sexually dimorphic character; mtp, midterminal process; ps, penile spine; ss1/3: sensory spot type 1/3; se, perispinal seta; sp, spinous process; * indicates that the presence of the character varies among the specimens. LD: laterodorsal; MD: middorsal; ML: midlateral; PD: paradorsal; PL: paralateral; SD: subdorsal; VL: ventrolateral; VM: ventromedial. 
spine on segment 10 and the presence of a midterminal process. Zelinka furthermore illustrate the type 3 sensory spots on the terminal segment as being non-elevated, and marks the putative perforation site of a paralateral seta on the segment as being present at least in the female.

\section{Paracentrophyes cf. quadridentatus - Faroe Islands population}

\section{Material Examined}

Two females (ZMUC KIN-112 and KIN-113) and two males (ZMUC KIN-107 and KIN-116) mounted for LM, and three males and one female mounted for SEM (MVS' personal collection). All material is stored at the Zoological Museum, Natural History Museum of Denmark.

\section{Brief Description}

The four specimens mounted for LM were measured. See Tables $\mathbf{1}$ and $\mathbf{2}$ for measurements and dimensions, and Table 4 for summary of positions of outer cuticular structures.

The distributional pattern and general appearance of appendages on the mouth cone and introvert are identical with the conditions found in $P$. anurus sp. nov. (see Fig. 3). The pectinate fringe found on the large outer oral styles has nine fringe tips, whereas the fringes on the smaller styles that
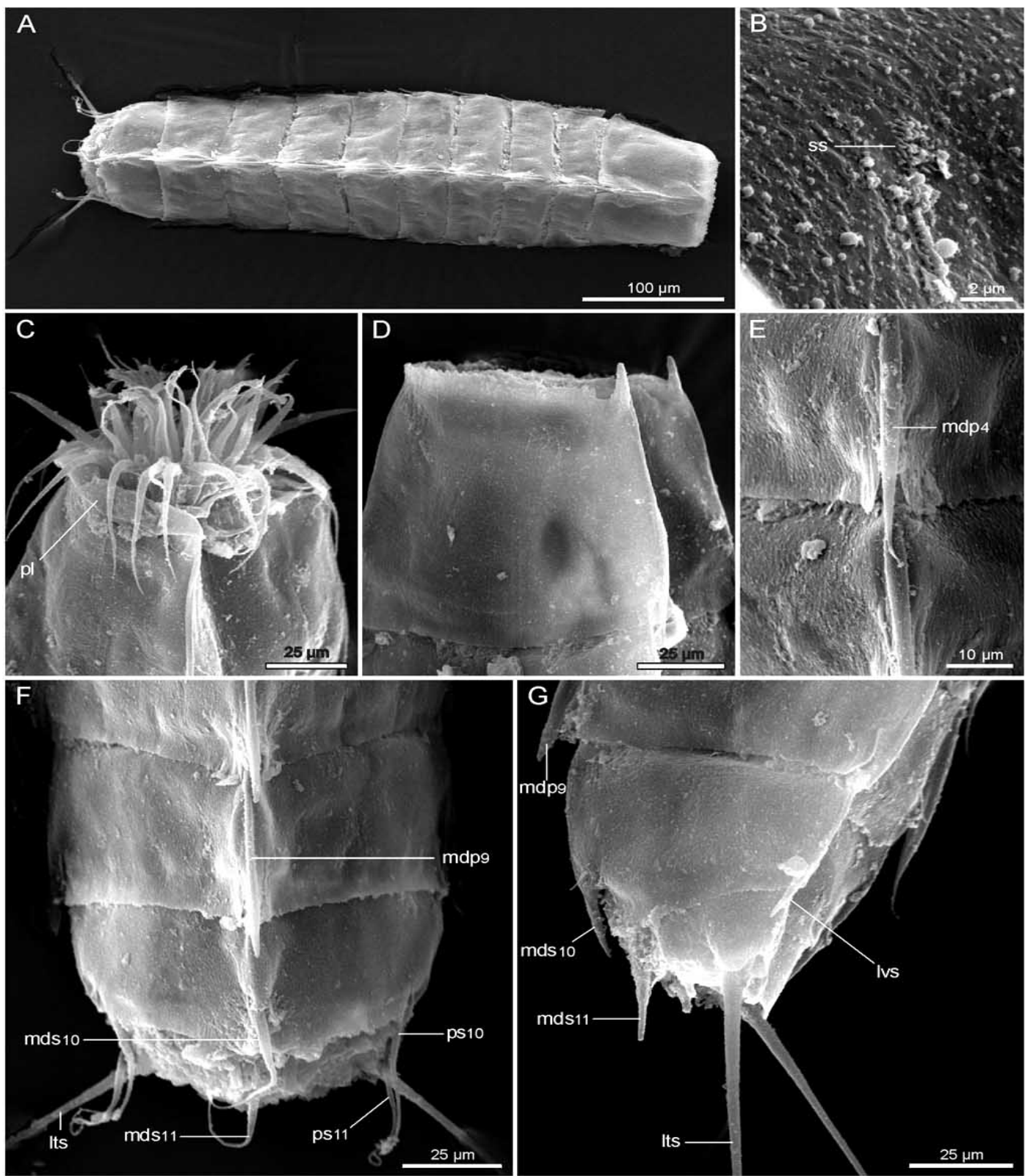

Fig. (10). Scanning electron micrographs showing cuticular head and trunk details in Paracentrophyes cf. quadridentatus from Spain. (A) Trunk of male specimen in dorsal overview. (B) Detail showing ventrolateral sensory spot on segment 4 . (C) Segment 1 and partly retracted introvert, ventrolateral view. (D) Segment 1 with head completely retracted, midlateral view. (E) Middorsal processes of segments 4 and 5. (F) Segments 8 to 11 in male, dorsal view. (G) Segments 9 to 11 in female, lateral view. Abbreviations: lts, lateral terminal spine; mdp, middorsal process; mds, middorsal spine; mls, midlateral spine; pl, placid; ps, penile spine; vlss, ventrolateral sensory spot. Digit after the labels refers to the segment number. 


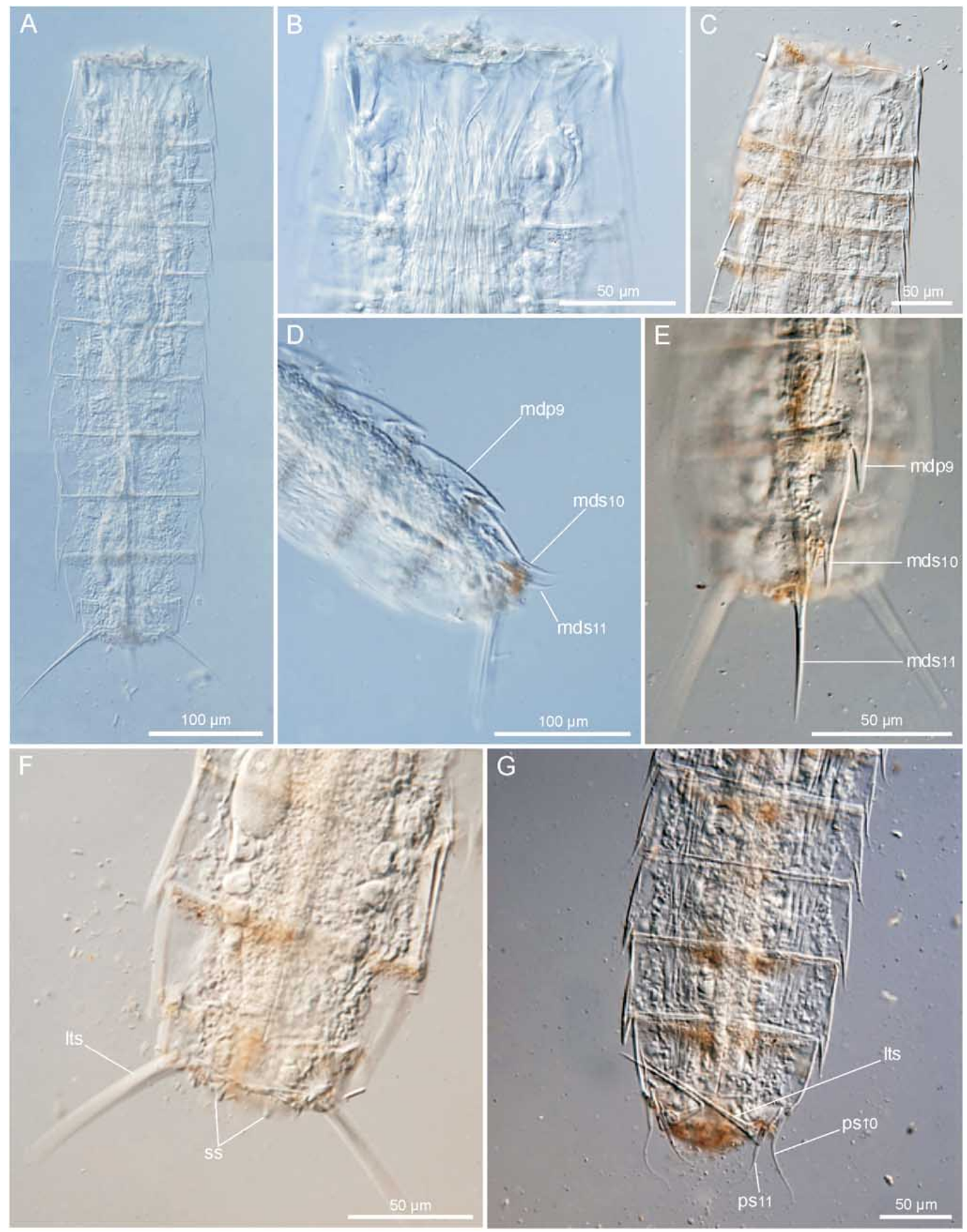

Fig. (11). Light micrographs showing cuticular and internal details in Paracentrophyes cf. quadridentatus from Spain. (A) Overview of female specimen. (B) Segment 1, ventral view. (C) Segments 1 to 5, ventrolateral view. (D) Segments 8 to 11 in male specimen, lateral view. (E) Segments 8 to 11 in female specimen, dorsal view. (F) Segments 9 to 11 in female specimen, ventral view. (G) Segments 7 to 11 in male specimen, ventral view. Abbreviations: lts, lateral terminal spine; mdp, middorsal process; mds, middorsal spine; ps, penile spine. Digit after the labels refers to the segment number.

tend to wrap halfway around the style have seven fringe tips (Fig. 9A).

The specimens are generally large, up to a trunk length of $669 \mu \mathrm{m}$, which constitutes the maximum trunk length of all Paracentrophyes spp. examined in the present study. Sternal width almost reaches its maximum around segment 4 or 5 and is retained down to segment 7 or 8 .
Segment 1 has one pair of paradorsal and ventrolateral perispinal setae (Fig. 9B), whereas the following nine segments possess one pair of setae in paradorsal, paralateral and ventrolateral positions. Distribution of setae does not differ between the sexes. Middorsal spinose processes are present on segments 1 to 9 , whereas the processes have been replaced by acicular spines on segments 10 and 11 (Figs. 7E, 
8E, 9C). Middorsal spine on segment 10 in females is very short, not or only hardly projecting over posterior margin of segment 11 (Fig. 7E). Middorsal spines on segments 10 and 11 are rigid in females but soft and flexible in males. Males furthermore have one pair of flexible penile spines in laterodorsal positions on segments 10 and 11 (Fig. 9C, F). Both pairs of sternal sensory spots on segment 10 are located in a ventromedial position (Fig. 9D). Two pairs of short subdorsal type 3 sensory spots and one pair of much longer ventromedial type 3 sensory spots are present on segment 11 . The long ventromedial sensory spots in females are only slightly elevated (Fig. 7F), whereas the male sensory spots are elevated on triangular bases with thread-like outgrowths on the outer lateral margins (Figs. 8F, 9F). The presence of a midterminal process varies among the examined specimens. Both females mounted for LM had a minute midterminal process (Fig. 7F), whereas its presence could not be confirmed on the female specimen mounted for SEM (Fig. 9E). One male mounted for LM had a much more prominent midterminal process (Fig. 8F), whereas the process could not be found on the second male mounted for LM. Both specimens had well-developed testes. The midterminal process could not be located in any of the three males mounted for SEM.

\section{Paracentrophyes cf. quadridentatus - Spain population}

\section{Material Examined}

One male (Fig. 10A, F) and one female (Fig. 10G) were mounted for SEM, and two females (Fig. 11A, E, F) and one male (Fig. 11D, G) for LM. All material is stored at the Universidad Complutense de Madrid, Spain, in FP's personal collection.

\section{Brief Description}

Measurements for specimens mounted for LM are given in Tables $\mathbf{1}$ and $\mathbf{2}$. See Table $\mathbf{4}$ for summary of positions of outer cuticular structures.

All specimens from the Spanish population appeared with the introvert withdrawn or only partially extended (Fig. 11C), so no data are available for scalids in the introvert or mouth cone and oral styles.
The sizes of the specimens agree in general terms with the animals in the Faroe population and are clearly apart from those of $P$. praedictus. Sternal width almost reaches its maximum around segment 4 and is retained down to segment 7 or 8 (Table $\mathbf{1}$ and 2, but see also Fig. 11A).

Segment arrangement and plate distribution is the same as described above for the Faroe Islands specimens. The anterior margin of segment 1 is finely denticulated with a pair of frontal projections at the tergosternal junction (Figs. 10D, 11B-C). An indication of a differentiation into a two episternal and a midsternal plate is present, although very indistinct, near the anterior margin of segment 1 (Fig. 11B). Trunk segments 1 to 10 in females and 1 to 9 in males show a broad, free posterior flap finely striated, although the very edge is quite smooth, without pectinate fringe (Fig. 10E-G). The cuticular surface, as revealed by SEM, do not show hairs arranged in distinct patterns. Hairs are instead regularly distributed over the surface. The hairs are minute, pointed scales not detached from the surface.

Presence and distribution of perispinal setae are the same as described for the Faroe specimens. Distribution of setae does not differ between the sexes. Middorsal spinose processes are present on segments 1 to 9 in both sexes, whereas in females have rigid, acicular spines on segments 10 and 11 (Figs. 10G, 11E), and males longer and more flexible spines (Figs. 10A, F, 11D, G). Males furthermore have one pair of laterodorsal penile spines on segments 10 and segment 11 (Figs. 10F, 11G). Sensory spots are inconspicuous and difficult to locate even with SEM (Fig. 10B). A midterminal process is present in all studied individuals of both sexes, although it is clearly smaller and very short in females.

\section{DISCUSSION}

\section{Meristic and Previously Proposed Diagnostic Characters for Paracentrophyes}

The three currently described species of Paracentrophyes are not easily distinguished, and the two populations of $P$. cf. quadridentatus from Spain and the Faroe Islands add further complexity to the taxonomy of the genus. Due to the somehow superficial description of $P$. quadridentatus and

Table 5. Summary of Differences and Key Characters Among the Examined Species of Paracentrophyes. Important or Unique Diagnostic States are Boldfaced

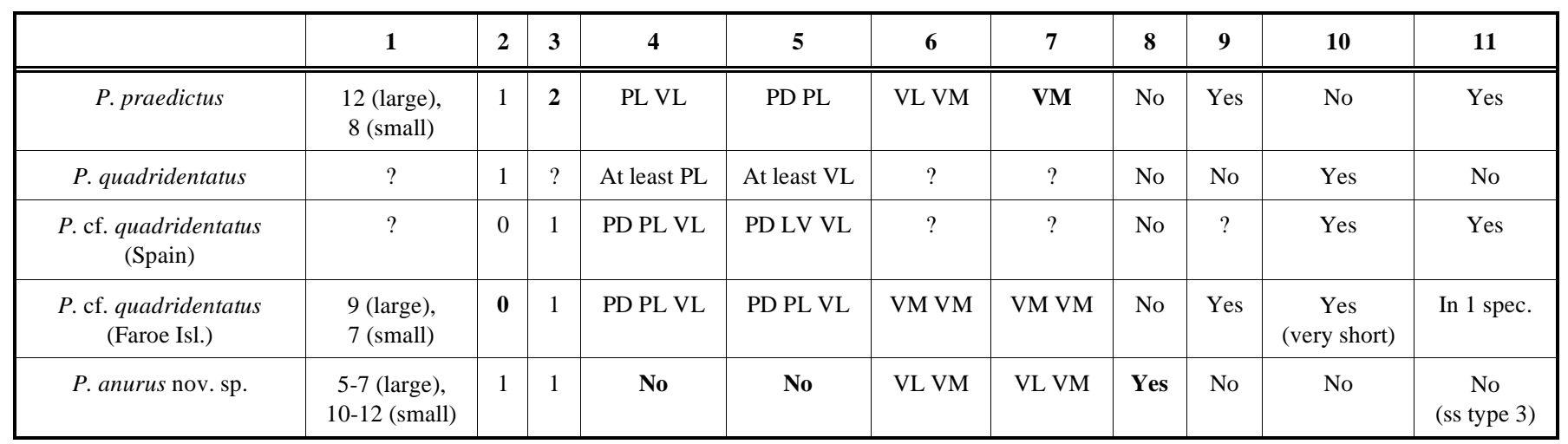

Characters: 1: Number of fringe tips on large and small outer oral styles. 2: Number of paralateral perispinal setae on segment 1. 3: Number of ventrolateral perispinal setae on segment 1. 4: Occurence and position of perispinal setae on segment 10 in females. 5: Occurence and position of perispinal setae on segment 10 in males. 6: Occurence and position of sensory spots on sternal plate of segment 10 in females. 7: Occurence and position of sensory spots on sternal plate of segment 10 in males. 8 : Middorsal spine on segment 10 in females extending over and beyond segment 11. 9: Ventromedial type 3 sensory spots on segment 11 in males on triangular elevation with thread-like extensions on margin. 10: Caudal process present in females. 11: Caudal process present in males. Abbreviations: PD, paradorsal; PL, paralateral; ss, sensory spot; VL, ventrolateral, VM, ventromedial. 
loss of type material, the specimens from Spain and the Faroe Islands cannot with certainty be considered conspecific with $P$. quadridentatus, but with this in mind, we choose to treat them as $P$. cf. quadridentatus in the following. A general overview of selected character traits that vary among the examined species and populations is summarized in Table $\mathbf{5}$.

Based on trunk lengths only, $P$. praedictus appears to be the shortest species with sizes ranging from 332 to $503 \mu \mathrm{m}$, however this range overlaps with the somehow dubious trunk lengths $(370 \mu \mathrm{m}$ and $595 \mu \mathrm{m})$ reported for $P$. quadridentatus (see Tables $\mathbf{1}$ and 2). Paracentrophyes anurus sp. nov. is among the largest species within the genus (595 to $630 \mu \mathrm{m}$ ), but again, this range overlaps with the Faroese population of $P$. cf. quadridentatus (568 to $669 \mu \mathrm{m}$ ). Hence, overall trunk lengths can, at the best, only be used as a supplement with other characters.

Higgins [2] uses the combined sternal widths to distinguish between $P$. praedictus and $P$. quadridentatus, noting that the latter possess a rather constant sternal width throughout most of the trunk whereas $P$. praedictus tapers gradually along the posterior third of the trunk. New measurements made on type specimens of $P$. praedictus (see Tables $\mathbf{1}$ and 2) reveal that the sternal width reaches its maximum and stays constant from segment 4 to 6 in males and segments 5 to 8 in females. According to the measures provided by Zelinka [1], the male sternal width is constant from segment 2 to 9 and the female from segment 2 to 8 . Hence, the overall trunk shape may serve as a guideline to distinguish between the two species. In females of $P$. anurus sp. nov., maximum sternal width is retained from segment 5 to 8 , thus being identical with females of $P$. praedictus. In males of $P$. anurus sp. nov. it increase with only $3 \mu \mathrm{m}$ from segment 3 to 8 , and reaches its maximum in segments 7 and 8. Males and females of the Faroese population of $P$. cf. quadridentatus reach their maximum sternal widths in segments 5 to 7 and 6 to 8 , respectively, whereas the Spanish population reach their maximum sternal widths in segments 4 to 8 in males and 4 to 7 in females. By including the new information from specimens collected after Higgins' [2] studies, it appears that also ranges in sternal widths show much overlap between the species and populations (see summary in Table 5), thus also this character should be used with caution.

Besides the trunk dimensions, Higgins [2] propose following characters to distinguish between $P$. praedictus and $P$. quadridentatus: Dissimilarities in differentiation into episternal and midsternal plates of sternal plate in segment 1 , lack of sensory spots, and lack of midterminal process in males of $P$. quadridentatus. In this context, we would question at least two of the proposed characters. The exact differentiation of the episternal and midsternal plates in $P$. quadridentatus cannot be judged from the illustrations in Zelinka's monograph [1] alone. It should be noted, however, that only a slight indication of a midsternal plate can be observed at the anterior margin in the Atlantic populations (Fig. 11B). We would also hesitate in concluding that $P$. quadridentatus does not possess any sensory spots at all. It seems more likely that Zelinka [1] simply left out this information, or was unable to see them. The latter is a possible explanation if his specimens resemble those from the Spanish population, as their sensory spots are difficult to discern, even with SEM (Fig. 10B). This leaves the occurrence of the midterminal process as the only diagnostic trait. This character will be discussed further below.

\section{Diagnostic Characters for Species of Paracentrophyes}

Considering the limited amount of information about morphological and potential diagnostic characters for $P$. quadridentatus, we will, in the following, mainly focus on $P$. praedictus, $P$. anurus sp. nov. and the two populations of $P$. cf. quadridentatus from the Atlantic. A detailed comparison of the species reveals that they differ at several points (see Table 5), even though most differences regard minor, somehow subtle details. Unique characters for $P$. anurus sp. nov. include the complete absence of setae on segment 10 , the long middorsal spine on segment 10 in females that extends considerably over the posterior margin of the terminal segment, and the midterminal type 3 sensory spot found in males. All three characters are visualized relatively easily, and make it fairly easy to discriminate $P$. anurus sp. nov. from other species. Male specimens of $P$. praedictus can be recognized by having only a single sensory spot on each sternal plate of segment 10, opposed to two sensory spots in all other examined species. However, the best diagnostic character that relate to both male and female specimens of $P$. praedictus is the presence of two pairs of ventrolateral perispinal setae on segment 1 . Both $P$. anurus sp. nov. and the examined specimens of $P$. cf. quadridentatus showed only one pair of setae in this position.

Other potentially diagnostic characters concern details on the outer oral styles and the midterminal process. During SEM examinations of $P$. anurus sp. nov. and $P$. cf. quadridentatus (Faroe Islands population), and examinations of SEM photos showing the detailed head morphology in $P$. praedictus [2] it was noted that all species possess a small fringe basally on the outer oral styles, but that the appearance and number of fringe tips showed interspecific variation. Paracentrophyes praedictus and $P$. cf. quadridentatus (Faroe Islands population) showed twelve and nine (Fig. 9A) fringe tips, respectively, at the bases of the large oral styles, whereas $P$. anurus sp. nov. showed only five to seven (Fig. 4B). Contrarily, $P$. anurus sp. nov. showed more fringe tips, ten to twelve, around the smaller oral styles, whereas $P$. praedictus and $P$. cf. quadridentatus showed only eight and seven, respectively. Further examinations are required to determine whether this character is constant within each species, but it could be potentially species diagnostic.

Another interesting, and potentially diagnostic character, relates to the development of the midterminal process on segment 11. Higgins [2] originally described the $P$. praedictus male as possessing a flexible middorsal spine and a short midterminal spine or process, whereas he misinterpreted the female middorsal spine as being midterminal, and hence analogous with the short midterminal process in the male. However, the long, spinous appendage found on segment 11 in females of all examined species is clearly dorsal, rather than midterminal and should accordingly be referred to as a middorsal spine. This conclusion is confirmed by the presence of both middorsal spine and midterminal process in female specimens of $P$. 
quadridentatus [1] and $P$. cf. quadridentatus from the two Atlantic populations (Fig. 7E-F).

The occurrence of a midterminal process related to the sex shows variation among the examined species, and it could represent another species diagnostic trait. In $P$. praedictus the midterminal process is present in males only [2], whereas Zelinka [1] describes it as being present in only females of $P$. quadridentatus. In the Spanish population of $P$. cf. quadridentatus both males and females have a midterminal process, whereas Faroe Islands included specimens of both sexes with and other without the process. Based on the apparently consistent occurrence of the midterminal process in $P$. praedictus and its complete absence in $P$. anurus sp. nov., the character obviously has some potential as being species diagnostic, but the more inconsistent occurrence among specimens of $P$. cf. quadridentatus stresses that it needs to be further explored.

\section{Current Taxonomic Status of Paracentrophyes}

Currently, three valid species, $P$. quadridentatus, $P$. praedictus and $P$. anurus sp. nov., can be assigned to the genus Paracentrophyes. As discussed above, the two latter species can be considered as well-defined, whereas $P$. quadridentatus is in urgent need of a redescription. Due to the missing information about this species, it is currently not possible to determine whether the specimens of the two Atlantic populations are conspecific with $P$. quadridentatus or if they represent one, or less probably, two distinct species. Based on the apparent presence of a midterminal process in females, we tentatively consider the Atlantic specimens as conspecific with $P$. quadridentatus but would like to stress that this assignment is not conclusive. If it is so, those populations constitute the first report for the species in the Atlantic Ocean. Future studies on the genus should focus on collection and redescription of $P$. quadridentatus from its type locality in the Bay of Naples, and molecular characterization of the known species and populations.

\section{ACKNOWLEDGEMENTS}

We wish to thank Stine Elle for preparing the line art illustrations and the Smithsonian Institution for loaning us specimens of Paracentrophyes praedictus. We are furthermore indebted to Dr. Won Gi Min and Taewook Kang for their assistance in collecting samples. This work has been conducted with support through the research program of KORDI with contract No. PM55551 to HSR, the Ministerio de Ciencia e Innovacion (Grant No. CGL2005-04310/BOS) to FP, and by the Danish Natural Science Research Council (Grant No. 272-08-0576) to MVS.

\section{REFERENCES}

[1] Zelinka C. Monographie der Echinodera. Verlag Wilhelm Engelmann, Leipzig, 1928, p. 3965.

[2] Higgins RP. The Atlantic barrier reef ecosystem at Carrie Bow Cay, Belize, II: Kinorhyncha. Smithson Contrib Mar Sci 1983; 18 1-131.

[3] Neuhaus B. Postembryonic development of Paracentrophyes praedictus (Homalorhagida): neoteny questionable among the Kinorhyncha. Zool Scr 1995; 24: 179-192.

[4] Sørensen MV, Pardos F. Kinorhynch systematics and biology - an introduction to the study of kinorhynchs, inclusive identification keys to the genera. Meiofauna Mar 2008; 16: 21-73.

[5] Kristensen RM, Higgins RP. Revision of Styraconyx (Tardigrada: Halechiniscidae), with description of two new species from Disko Bay, West Greenland. Smithson Contrib Zool 1984; 391: 1-40.

[6] Pardos F, Higgins RP, Benito J. Two new Echinoderes (Kinorhyncha, Cyclorhagida) including a reevaluation of kinorhynch taxonomic characters. Zool Anz 1998; 237: 195-208.

[7] Neuhaus B, Higgins RP. Ultrastructure, biology and phylogenetic relationships of Kinorhyncha. Integr Comp Biol 2002; 42: 619-632.

[8] Sørensen MV, Rho HS, Kim D. A new species of Condyloderes (Cyclorhagida, Kinorhyncha) from Korea. Zool Sci 2010; 27: 234242. 